\title{
Social Influence in the Global Diffusion of Alternative Fuel Vehicles - A Meta-Analysis
}

\author{
Pettifor, H.*
}

h.pettifor@uea.ac.uk, 01603-592547, Tyndall Centre for Climate Change Research, University of East Anglia, Norwich NR4 7TJ, UK

Wilson, C.

charlie.wilson@uea.ac.uk, 01603-591386, Tyndall Centre for Climate Change Research, University of East Anglia, Norwich NR4 7TJ, UK

Axsen, J.

jaxsen@gmail.com, (778) 782-4659, School of Resource and Environmental Management, Simon Fraser University, 8888 Univesity Drive, Burnaby, B.C. V5A 1S6

Abrahamse, W.

Wokje.abrahamse@vuw.ac.nz, +44 4463 5217, School of Geography, Environment and Earth Sciences, Victoria University of Wellington, New Zealand

Anable, J.

j.anable@abdn.ac.uk, 01224 273795, The Centre for Transport Research, University of Aberdeen, Old Aberdeen, AB24 3UE

* author for correspondence

\section{Abstract}

Alternative fuel vehicle technologies are needed to mitigate rising greenhouse gas emissions from transport. Social influence is integral to the diffusion of private vehicles which are highly visible and fulfil practical as well as social functions. This paper provides the first meta-analysis of empirical studies which measure the strength of social influence on consumer vehicle choice. A systematic literature review identified 21 studies that examined three types of social influence: interpersonal communication; neighbourhood effect; and conformity with social norms. A random effects metaanalysis found a significant and small to moderate effect of social influence on vehicle choices $(r=0.241, p<.001)$. The overall effect size did not vary significantly between types of social influence nor between types of vehicle (conventional or alternative fuel). However, further analysis using meta-regression found that heterogeneity in social influence effect size across studies was explained by differences in countries' cultural receptiveness to normative influence. These findings have important implications for policy and modelling analysis of alternative fuel vehicle adoption, for which diffusion is both a socially and culturally-mediated process.

\section{Highlights ( $\max 6, \max 60$ characters each)}

- Meta-analysis of 21 empirical studies

- Robust evidence of social influence on vehicle choice

- Three types of social influence have similar effects

- Strength of social influence similar for conventional and alternative fuel vehicles

- Cultural differences between countries

Keywords ( $\max 6)$

Vehicle choice, social influence, meta-analysis, AFVs 


\section{Introduction}

Vehicle choice studies typically represent the consumer as a rational decision maker, evaluating alternatives in terms of price, running costs and other functional vehicle attributes such as reliability, speed, performance, range (Wilson et al., 2014). Capital costs, income, and past experience (brand loyalty) are found to be the principal determinants of vehicle choice, although gender, age and education can also be important (Achtnicht et al., 2012; Batley et al., 2004). Vehicle choice studies focus on the individual car buyer with limited consideration of the influence of others and the context in which cars are acquired. But vehicle ownership is not only a practical necessity for personal mobility. Vehicles also satisfy symbolic and social needs including expressing self-identity, conveying status to others, and attaining group membership (Axsen et al., 2013; Schuitema et al., 2013).

Relatively few empirical studies account for any form of social influence on vehicle choice. By social influence, we mean influences on individual choices from the behaviour and opinion of others. In a review of 53 empirical studies of household demand for AFVs, Turcksin et al. (2013) observed a tendency for studies to 'understate and under-test the symbolic meanings people attach to vehicle purchases'. This omission (or simplification) ignores the social embeddedness of transportation within economic systems, and amounts to what Granovetter (1985) refers to as an 'under-socialised $v^{\text {view' }}$ ' ef economic behaviour. Studies that measure social influence explicitly recognise consumers as individuals, but also members of families, households, neighbourhoods and social networks (Axsen et al., 2013; Jackson, 2005; Peattie, 2010).

Many aspects of consumer behaviour are culturally determined (de Mooij and Hofstede, 2011). Monetary influences such as personal income have been strongly associated with vehicle choice, with national wealth reliably predicting variation in vehicle ownership across countries. However, empirical research suggests this emphasis is shifting in favour of other behavioural characteristics consistent with cultural difference (Aini et al., 2013; de Mooij and Hofstede, 2002; Gallez, 1994). National cultures connect individuals through similar value systems which can endure over long periods of time, shaping political and economic development as well as consumer choices (Inglehart and Baker, 2000; Kim and Markus, 1999; Kim and Drolet, 2003; Liang and He, 2012). The wealthier that countries become, the more influence that culture has on choice as people become more likely to spend their discretionary income on what best fits their value system (de Mooij and Hofstede, 2002). As an example, vehicle purchase decisions in rapidly developing countries such as China and India are expected to become more heterogeneous as people get wealthier (de Mooij and Hofstede, 2002).

Globally $95 \%$ of transportation energy is derived from fossil fuels. Transport accounts for $23 \%$ of energy-related $\mathrm{CO}_{2}$ emissions. Despite new technologies and policies, overall transport emissions have grown faster than in any other end-use sector since 1970, with around $80 \%$ of the increase attributable to road vehicles (Sims et al., 2014). Climate change mitigation requires widespread adoption of more efficient vehicles and alternative fuel vehicles (AFVs). Although a peak in personal daily travel by car has occurred in some developed economies (Metz, 2010), demand for vehicle ownership is increasing in emerging economies such as China and India (Figueroa et al., 2014; Helveston et al., 2015). Less than $7 \%$ of privately owned light duty vehicles use alternative fuels (including hybrid-electric vehicles powered by petrol or diesel) (Beltramello, 2012). Understanding consumers' vehicle choices is important as AFVs are integral to a low carbon transition.

The aim of this paper is to improve understanding of vehicle choice as a socially and culturally mediated process. Specifically, we answer two research questions: (1) Is there robust empirical 
evidence that social influence affects the vehicle choices of private users? (2) Does social influence vary between countries as a result of cultural differences? We build on earlier work by Maness et al. (2015) Potoglou and Kanaroglou (2008), Sharmeen et al. (2014) and Sunitiyoso et al. (2013), examining the importance of social and spatial interactions between individuals in making transport choices.

To address these questions we use meta-analysis, a rigorous methodology in which findings from individual empirical studies are pooled and effect sizes are tested for significance in order to derive overall conclusions about the outcome of interest (Borenstein et al., 2009).

\section{Social influence and vehicle choice}

\subsection{Types of social influence}

Meta-analysis relies on underlying studies being identified and collected in a reliable and systematic manner (Borenstein et al., 2009). This involves a clear search strategy using specific keywords to identify relevant studies, recording important study characteristics such as conceptual framing, methodological approach, study design, as well as key findings including effect size (Gough et al., 2012). We conducted a systematic literature review using a comprehensive set of defined keywords to identify studies that empirically examined the relationship between social influence and vehicle choices (see Appendix A). We identified a total of 43 studies from 16 different countries spanning the period 1967 to 2014 . We reviewed the conceptual framework, methodology and results of each study. We identified three types of social influence that were distinguished empirically: (1) interpersonal communication (2) neighbourhood effect (3) social norms (see Table 1). In the next sections we synthesise key findings and insights for each type.

Table 1 - Types of Social Influence on Vehicle Choice in Empirical Studies

\begin{tabular}{|c|c|c|c|}
\hline $\begin{array}{l}\text { Type of social } \\
\text { influence }\end{array}$ & Definition & Examples from Empirical Studies & Empirical Studies \\
\hline $\begin{array}{l}\text { Interpersonal } \\
\text { communication }\end{array}$ & $\begin{array}{l}\text { The exchange of } \\
\text { information about an } \\
\text { innovation between } \\
\text { members of a social } \\
\text { network which both } \\
\text { informs and persuades } \\
\text { adoption decisions } \\
\text { (Granovetter, 1973; } \\
\text { Valente, 1996; } \\
\text { Wellman, 1988). This } \\
\text { includes electronic word } \\
\text { of mouth (eWOM) } \\
\text { where online } \\
\text { communities make } \\
\text { recommendations to } \\
\text { each other (eg through } \\
\text { social media or } \\
\text { consumer websites). }\end{array}$ & $\begin{array}{l}\text { Seeking advice on vehicle } \\
\text { purchase from a trusted family } \\
\text { member, from a friend who has } \\
\text { some first-hand experience or } \\
\text { guidance from a co-worker who } \\
\text { has recently bought a new } \\
\text { vehicle (Axsen et al., 2013; Baltas } \\
\text { and Saridakis, 2013; Gaker et al., } \\
\text { 2010). Being influenced by other } \\
\text { members of a social media } \\
\text { network through on-line } \\
\text { conversations about experiences } \\
\text { (Hutter et al., 2013), or using } \\
\text { other consumers' experiences } \\
\text { from a known and trusted online } \\
\text { source. }\end{array}$ & $\begin{array}{l}\text { Axsen and Kurani (2012), Axsen et } \\
\text { al. (2013), Baltas and Saridakis } \\
\text { (2013), Belgiawan et al. (2013), Bell } \\
\text { (1967), Dijk et al. (2013), Eppstein } \\
\text { et al. (2011), Feng and Papatla } \\
\text { (2012), Gaker et al. (2010), Heffner } \\
\text { et al. (2007), Hsu et al. (2013), } \\
\text { Hutter et al. (2013), Kim et al. } \\
\text { (2011), Kulkarni et al. (2012), } \\
\text { Mohammad Reza and Neda (2012), } \\
\text { Sha et al. (2012), Shafiei et al. } \\
\text { (2012), Schuitema et al. (2013), } \\
\text { Ting et al. (2011), Zhang et al. } \\
\text { (2011). }\end{array}$ \\
\hline $\begin{array}{l}\text { Neighbourhood } \\
\text { effect }\end{array}$ & $\begin{array}{l}\text { Information gained from } \\
\text { observing vehicles being } \\
\text { demonstrated by others } \\
\text { in close physical } \\
\text { proximity. This helps } \\
\text { reduce perceived } \\
\text { technological and social }\end{array}$ & $\begin{array}{l}\text { Gaining new information about a } \\
\text { particular vehicle or vehicle } \\
\text { technology when it is owned by } \\
\text { close neighbours (McShane et } \\
\text { al., 2012). Learning about new } \\
\text { vehicle technology (e.g., hybrids) } \\
\text { through seeing it used by others }\end{array}$ & $\begin{array}{l}\text { Heffetz (2011), McShane et al. } \\
\text { (2012), Adjemian et al. (2010), } \\
\text { Goetzke and Weinberger (2012), } \\
\text { Grinblatt et al. (2008), Heffetz } \\
\text { (2011), Heutel and Muehlegger } \\
\text { (2010) Shemesh and Zapatero } \\
\text { (2014), Yang and Allenby (2003). }\end{array}$ \\
\hline
\end{tabular}




\begin{tabular}{|c|c|c|c|}
\hline & $\begin{array}{l}\text { uncertainties (Rogers, } \\
\text { 2003; Young, 2009). }\end{array}$ & $\begin{array}{l}\text { and gaining positive insight } \\
\text { (Heutel and Muehlegger, 2010). } \\
\text { Closely observing the } \\
\text { composition of the surrounding } \\
\text { vehicle fleet (Adjemian et al., } \\
\text { 2010; Goetzke and Weinberger, } \\
\text { 2012). }\end{array}$ & \\
\hline Social norms & $\begin{array}{l}\text { Information gained on } \\
\text { the rules and standards } \\
\text { of behaviour of referent } \\
\text { social groups, which } \\
\text { induces compliance, } \\
\text { imitation, or 'herd } \\
\text { behaviour' (Cialdini and } \\
\text { Goldstein, 2004; Cialdini } \\
\text { and Trost, 1998). }\end{array}$ & $\begin{array}{l}\text { Vehicle choices are guided by } \\
\text { beliefs as to the social } \\
\text { acceptability of owning a } \\
\text { particular vehicle (alternative } \\
\text { fuel or otherwise) (Jansson et al., } \\
\text { 2010; Moons and De Pelsmacker, } \\
\text { 2012). Choices are guided by } \\
\text { moral obligations to act in favour } \\
\text { of the common good with } \\
\text { respect to saving energy from } \\
\text { vehicle use (Aini et al., 2013). }\end{array}$ & $\begin{array}{l}\text { Aini et al. (2013), Axsen et al. } \\
\text { (2009), Donnelly Jr and Ivancevich } \\
\text { (1974), Eggers and Eggers (2011), } \\
\text { Graham-Rowe et al. (2012), Heutel } \\
\text { and Muehlegger (2010), Huétink et } \\
\text { al. (2010), Moons and De } \\
\text { Pelsmacker (2012), Jansson et al. } \\
\text { (2010). }\end{array}$ \\
\hline
\end{tabular}

\subsection{Interpersonal communication}

Interpersonal communication describes the exchange of information about innovation attributes through the structured set of links between individuals within a social system (Granovetter, 1973; Valente, 1996; Wellman, 1988). Interpersonal communication between members of a connected social group (such as a family or friendship network) both informs and persuades vehicle choice. Empirical research shows that vehicle choices are influenced by the opinions of known or trusted others (Axsen et al., 2013; Wiedmann et al., 2011; Zhang et al., 2011). In their study in the UK, Axsen et al. (2013) found the majority of respondents within their small scale survey of electric vehicles reported at least one social interaction as being highly influential over their preferences. Zhang et al. (2011) found the likelihood of purchasing a particular vehicle type in China within a 5 year period was significantly increased with the positive opinion of peers.

Consistent with theoretical insight, the propensity to be influenced and to influence others varies (Axsen and Kurani, 2011; Belgiawan et al., 2013; Donnelly Jr and Ivancevich, 1974; Sha et al., 2012; Wiedmann et al., 2011). Social ties between individuals vary in strength depending on emotional proximity, frequency of social interactions, and in particular the extent to which people rely on each other for advice, information and guidance (Granovetter, 1973). Social influence is moderated by the strength of social ties between family and friends (close and distant) (Axsen and Kurani, 2011) and family role (e.g., father, mother) (Belgiawan et al., 2013). Sha et al. (2012) found people living in the UK who are more informed about a particular technology were more likely to be influenced by the opinions of others within their close social network.

Within this type of social influence we also include people connected through social media or online communities (including internet websites), recognising the growth in this form of information exchange (Moreno-Munoz et al., 2016; Peres et al., 2010). For example, the 'Mini' brand has its own Facebook fan page through which members communicate. Hutter et al. (2013) found a positive association between membership and purchase intentions within Germany and that inspired members to communicate positively with others outside of this social network. Referred to as electronic word of mouth (eWOM), on-line conversations about new products within social networks are both increasing (Mohammad Reza and Neda, 2012) and having an effect on vehicle choices (Feng and Papatla, 2012; Hsu et al., 2013; Hutter et al., 2013; Sha et al., 2012; Ting et al., 2011). 


\subsection{Neighbourhood effect}

Information gained from observing vehicles demonstrated by others in close physical proximity helps to reduce perceived technological and social uncertainties (Adjemian et al., 2010). This is demonstrated in a number of studies that measure associations between the vehicle choices of people living in similar neighbourhoods. Choices made by others signal reliability and vehicle quality which is particularly relevant for vehicles with new fuel or body types with higher perceived risks (Adjemian et al., 2010; Heutel and Muehlegger, 2010). The neighbourhood effect thus describes a type of social influence that strengthens as a new vehicle becomes increasingly visible to others. Potential adopters improve their understanding of an innovation by seeing it demonstrated or trialled (Young, 2009) which can lead to faster adoption rates (Rogers, 2003). This is significant and distinguishable from information exchange within closely related socioeconomic groups (Goetzke and Weinberger, 2012; Grinblatt et al., 2008; Heffetz, 2011).

Vehicles are highly visible physical products used primarily in public environments. Within 31 different expenditure categories in the USA including clothing, jewellery, home furnishings and mobile phones, Heffetz (2011) found vehicles to be the second most visible to other people living in close proximity. People are more likely to own or purchase a certain type of car if people living around them have done so recently (Adjemian et al., 2010; Grinblatt et al., 2008; Mau et al., 2008). Although a strong neighbourhood effect is evident in both urban and rural communities (Goetzke and Weinberger, 2012; McShane et al., 2012; Yang and Allenby, 2003; Zhu and Chao, 2013), it can be stronger in rural areas with lower population density (Grinblatt et al., 2008; Shemesh and Zapatero, 2014).

The neighbourhood effect is also moderated by status beliefs about the owners of vehicles (Goetzke and Weinberger, 2012; Grinblatt et al., 2008; McShane et al., 2012). Grinblatt et al. (2008) found that people living in Finland are more likely to notice vehicles driven by referent income groups. McShane et al. (2012) found that people in the USA are more likely to notice vehicles typically driven by people of the same gender.

Although more commonly measured in empirical studies between households situated closely to each other (hence neighbourhood effect), other contexts including workplaces may similarly provide physical proximity to observe others' vehicle choices. The neighbourhood effect is also referred to as social influence that occurs within eyeshot (McShane et al., 2012).

\subsection{Social norms}

Social norms may be either descriptive (perceptions about what other people do, what is normal) or injunctive (perceptions about what other people approve or disapprove of, beliefs about what is acceptable behaviour for them) (Cialdini et al., 1991). Information gained on the rules and standards of behaviour of referent social groups can induce imitation or compliance (Banerjee, 1992; Cialdini and Goldstein, 2004; Cialdini and Trost, 1998).

Empirical studies show that acceptance of AFVs increases in line with greater evidence that other people have adopted (e.g., more vehicles on the road, changes in refuelling infrastructure) (Aini et al., 2013; Eggers and Eggers, 2011; Jansson et al., 2010; Mau et al., 2008; Ozaki and Sevastyanova, 2011; Schuitema et al., 2013). Potential adopters of a new technology receive specific signals or social cues from others and these are particularly strong when they come from referent or aspirational groups such as people of similar income levels or gender, opinion leaders, or 'change 
agents' who introduce innovations into a social network (Grinblatt et al., 2008; McShane et al., 2012; Peres et al., 2010). In one study in Malaysia compliance with social norms explained over $12 \%$ of the variance in purchase decisions of the Toyota Prius (Aini et al., 2013). Signals from referent social groups are particularly relevant to purchasers of luxury brands such as BMW for which vehicle choices convey messages to others on social status and identity (Schuitema et al., 2013; Shemesh and Zapatero, 2014).

A detailed ethnographic study of hybrid vehicle owners in the USA found owners were demonstrating values such as morality (concern for others), maturity (making a sensible decision) and independence (reducing support for oil producers) (Heffner et al. 2007). But this symbolism may detract potential adopters. Wiedmann et al. (2011) found men in Germany particular attach a high risk to owning an AFV when they believe their behaviour will be judged negatively by others.

Schuitema et al. (2013) found that people in the UK are less concerned about the negative symbolic effects of owning an electric vehicle if this is proposed as a second car rather than the primary vehicle. Although some studies suggest social norms are not as strong as individual attitudes (Moons and De Pelsmacker, 2012; Murtaugh and Gladwin, 1980), Jansson et al. (2010) find injunctive social norms are a stronger predictor of AFV adoption in Sweden than education, income and current ownership.

\section{Materials and Methods}

\subsection{Identification of studies suitable for meta-analysis}

A full discussion of the literature review is contained in Appendix A. Of the 43 studies identified through systematic literature review as measuring social influence effects on vehicle choice (conventional vehicles as well as AFVs), 29 studies were initially considered suitable for metaanalysis as they reported quantitative measures of social influence (see Appendix D). However, six studies were excluded because they did not report specific effect sizes for social influence. For example, various studies using discrete choice experiments and agent-based model simulations report post-estimation statistics such as willingness to pay (WTP) but these are not convertible to a comparable metric. A further two studies were excluded because they report outcome statistics that are not comparable to other studies (e.g., paired t-tests, rankings). A total of 21 studies were included in the meta-analysis and are summarised in Table 2 . Studies were included regardless of whether social influence was found to be significant; non-significant results were found in two studies.

Table 2 - Empirical studies included in the meta-analysis of social influence on vehicle choice $(\mathrm{N}=\mathbf{2 1})$

\begin{tabular}{|l|l|l|l|l|l|}
\hline Author(s) & Country & $\begin{array}{l}\text { Social influence } \\
\text { type }\end{array}$ & Target group & N & Outcome measure \\
\hline $\begin{array}{l}\text { Axsen et al. } \\
(2013)\end{array}$ & UK & $\begin{array}{l}\text { Interpersonal } \\
\text { communication }\end{array}$ & Workplace staff & 170 & $\begin{array}{l}\text { Vehicle choice between AFV and } \\
\text { conventional vehicle given } \\
\text { interactions with co-workers }\end{array}$ \\
\hline $\begin{array}{l}\text { Baltas and } \\
\text { Saridakis } \\
(2013)\end{array}$ & Greece & $\begin{array}{l}\text { Interpersonal } \\
\text { communication }\end{array}$ & Car drivers & 1,357 & $\begin{array}{l}\text { Choice between } 12 \text { alternative } \\
\text { fuel cars given pre-purchase } \\
\text { information from friends and } \\
\text { family. }\end{array}$ \\
\hline $\begin{array}{l}\text { Hsu et al. } \\
\text { (2013) }\end{array}$ & Taiwan & $\begin{array}{l}\text { Interpersonal } \\
\text { communication }\end{array}$ & $\begin{array}{l}\text { Car owners and } \\
\text { non-car owners }\end{array}$ & 1,594 & $\begin{array}{l}\text { Choice between vehicles given } \\
\text { influences of social networks } \\
\text { spreading eWOM }\end{array}$ \\
\hline Hutter et al. & Germany & Interpersonal & Potential & 311 & Purchase intention as a function \\
\hline
\end{tabular}




\begin{tabular}{|c|c|c|c|c|c|}
\hline (2013) & & communication & $\begin{array}{l}\text { customers of } \\
\text { specific } \\
\text { make/model }\end{array}$ & & of word of mouth \\
\hline $\begin{array}{l}\text { Kulkarni et al. } \\
\text { (2012) }\end{array}$ & USA & $\begin{array}{l}\text { Interpersonal } \\
\text { communication }\end{array}$ & $\begin{array}{l}\text { Buyers of family } \\
\text { sedans }\end{array}$ & 886 & $\begin{array}{l}\text { Choice between } 24 \text { family cars } \\
\text { given recommendations from } \\
\text { other consumers through online } \\
\text { resources }\end{array}$ \\
\hline $\begin{array}{l}\text { Mohammad } \\
\text { Reza and } \\
\text { Neda (2012) }\end{array}$ & Iran & $\begin{array}{l}\text { Interpersonal } \\
\text { communication }\end{array}$ & $\begin{array}{l}\text { Potential } \\
\text { customers of } \\
\text { specific } \\
\text { make/model }\end{array}$ & 341 & $\begin{array}{l}\text { Purchase intention as a function } \\
\text { of word of mouth }\end{array}$ \\
\hline $\begin{array}{l}\text { Sha et al. } \\
(2012)\end{array}$ & UK & $\begin{array}{l}\text { Interpersonal } \\
\text { communication }\end{array}$ & $\begin{array}{l}\text { Purchasers of } \\
\text { new vehicle }\end{array}$ & 4,544 & $\begin{array}{l}\text { Car ownership and propensity to } \\
\text { use word of mouth }\end{array}$ \\
\hline $\begin{array}{l}\text { Zhang et al. } \\
\text { (2011) }\end{array}$ & China & $\begin{array}{l}\text { Interpersonal } \\
\text { communication }\end{array}$ & $\begin{array}{l}\text { Driving school } \\
\text { pupils }\end{array}$ & 299 & $\begin{array}{l}\text { Willingness to adopt AFV as } \\
\text { function of peer effects }\end{array}$ \\
\hline $\begin{array}{l}\text { Adjemian et } \\
\text { al. (2010) }\end{array}$ & USA & $\begin{array}{l}\text { Neighbourhood } \\
\text { effect }\end{array}$ & $\begin{array}{l}\text { Households in } \\
\text { given census } \\
\text { region }\end{array}$ & 560 & $\begin{array}{l}\text { Purchase of specific car body } \\
\text { type given behaviour of others in } \\
\text { the same neighbourhood }\end{array}$ \\
\hline $\begin{array}{l}\text { Goetzke and } \\
\text { Weinberger } \\
(2012)\end{array}$ & USA & $\begin{array}{l}\text { Neighbourhood } \\
\text { effect }\end{array}$ & $\begin{array}{l}\text { People who } \\
\text { would buy small } \\
\text { vehicle }\end{array}$ & 3,322 & $\begin{array}{l}\text { Car ownership as a function of } \\
\text { characteristics of the } \\
\text { neighbourhood }\end{array}$ \\
\hline $\begin{array}{l}\text { Grinblatt et } \\
\text { al. (2008) }\end{array}$ & Finland & $\begin{array}{l}\text { Neighbourhood } \\
\text { effect }\end{array}$ & $\begin{array}{l}\text { Purchasers of } \\
\text { new vehicle }\end{array}$ & 211,173 & $\begin{array}{l}\text { Car purchase as a function of } \\
\text { purchases of near neighbours }\end{array}$ \\
\hline $\begin{array}{l}\text { Heutel and } \\
\text { Muehlegger } \\
\text { (2010) }\end{array}$ & USA & $\begin{array}{l}\text { Neighbourhood } \\
\text { effect }\end{array}$ & $\begin{array}{l}\text { Purchasers of } \\
\text { new vehicle }\end{array}$ & 4,630 & $\begin{array}{l}\text { AFV sales in given state as a } \\
\text { function of increased visibility } \\
\text { effects }\end{array}$ \\
\hline $\begin{array}{l}\text { McShane et } \\
\text { al. (2012) }\end{array}$ & USA & $\begin{array}{l}\text { Neighbourhood } \\
\text { effect }\end{array}$ & $\begin{array}{l}\text { Purchasers of } \\
\text { new vehicle }\end{array}$ & 1,000 & $\begin{array}{l}\text { Car purchase behaviour based on } \\
\text { within eyeshot purchases of near } \\
\text { neighbours }\end{array}$ \\
\hline $\begin{array}{l}\text { Shemesh and } \\
\text { Zapatero } \\
(2014)\end{array}$ & USA & $\begin{array}{l}\text { Neighbourhood } \\
\text { effect }\end{array}$ & $\begin{array}{l}\text { People who } \\
\text { purchased } \\
\text { new/used car }\end{array}$ & 8,981 & $\begin{array}{l}\text { Intentions towards purchase } \\
\text { luxury car given purchase } \\
\text { behaviour of near neighbours }\end{array}$ \\
\hline $\begin{array}{l}\text { Zhu and Chao } \\
\text { (2013) }\end{array}$ & USA & $\begin{array}{l}\text { Neighbourhood } \\
\text { effect }\end{array}$ & $\begin{array}{l}\text { Vehicle owners } \\
\text { including AFV }\end{array}$ & 15,884 & $\begin{array}{l}\text { Purchase choice of AFV as a } \\
\text { function of behaviour of near } \\
\text { neighbours }\end{array}$ \\
\hline $\begin{array}{l}\text { Aini et al. } \\
(2013)\end{array}$ & Malaysia & Social norms & $\begin{array}{l}\text { Government } \\
\text { workers }\end{array}$ & 201 & $\begin{array}{l}\text { Purchase intention towards AFVs } \\
\text { moderated by individual } \\
\text { subjective norms }\end{array}$ \\
\hline $\begin{array}{l}\text { Gaker et al. } \\
(2010)\end{array}$ & USA & Social norms & Students & 312 & $\begin{array}{l}\text { Choice between AFV and } \\
\text { conventional vehicle given } \\
\text { knowledge of behaviour of others }\end{array}$ \\
\hline $\begin{array}{l}\text { Jansson et al. } \\
(2010)\end{array}$ & Sweden & Social norms & Car owners & 1,832 & $\begin{array}{l}\text { Willingness to adopt a AFV as a } \\
\text { function of subjective norms }\end{array}$ \\
\hline $\begin{array}{l}\text { Moons and } \\
\text { De } \\
\text { Pelsmacker } \\
\text { (2012) }\end{array}$ & Belgium & Social norms & Students & 1,202 & $\begin{array}{l}\text { Intention to adopt AFV as a } \\
\text { function of subjective norms }\end{array}$ \\
\hline $\begin{array}{l}\text { Schuitema et } \\
\text { al. (2013) }\end{array}$ & UK & Social norms & Car owners & 2,729 & $\begin{array}{l}\text { Intention to adopt AFV as } \\
\text { function of symbolic benefits }\end{array}$ \\
\hline $\begin{array}{l}\text { Wiedmann et } \\
\text { al. (2011) }\end{array}$ & Germany & Social norms & Car owners & 480 & $\begin{array}{l}\text { Social risk involved in ownership } \\
\text { of AFV }\end{array}$ \\
\hline
\end{tabular}

Most outcome measures within the 21 studies are stated vehicle preferences (purchase intentions, willingness to adopt a particular vehicle type, choice between vehicle types). Only three studies report revealed vehicle preferences (current vehicle ownership). Sample sizes vary considerably from 170 employees of the same organisation to one exceptionally large sample of over 200,000 residents of Finland. All studies are based on data collected between 1999 and 2013. Although all respondents are either car drivers or of car driving age they vary in terms of the populations they represent. Some samples are drawn from populations of recent car purchasers $(n=5)$ and some of 
these are distinguished as single or multiple vehicle households $(n=4)$. Six samples are drawn from specific populations such as government workers, online panels, commuters, students and trainees in driving schools. Just over half of the studies $(n=11)$ are based on choice outcomes related to the purchase of AFVs with the rest $(n=10)$ based on conventional petrol or diesel vehicles. Most studies are based on data collected in the USA $(n=8)$ or a single Europe country $(n=9)$ namely the UK, Germany, Greece, Belgium, Sweden, and Finland. A single study is based on data collected in the Middle East (Iran), and 3 studies use data collected in Asia (Malaysia, China, Taiwan) (see Table 2).

Each study could also be characterised in terms of type of social influence based on the conceptual framework or methodological approach. Of the 21 studies, eight studies examined interpersonal communication including five which measured electronic word of mouth within online communities of like-minded consumers. Seven studies measured neighbourhood effect as a function of residential density, proximity to neighbours, previous car purchases of neighbours, and visual effects from local residents. Six studies measured the effects of social norms in terms of perceived social risk, social signalling through increased market share, and perceptions of socially appropriate behaviour.

\subsection{Analysis of data}

Meta-analysis involves the identification of a comparable metric for each study, and the weighting of relative effect size according to sample size. The comparable metric we identify between studies is the correlation coefficient ( $r$ ) since all studies report either betas, log odds (probits), or chi-square statistics. These are easily converted into a common metric: Fisher's Zr (Borenstein et al., 2009). The use of standardised regression coefficients (' $\beta$ ') as a metric of effect size is common within the social sciences (Borenstein et al., 2009; Rosenthal and DiMatteo, 2001). Social influence studies are also hampered by fundamental design issues including omitted variable bias which makes a multivariate design preferable to reduced form modelling (Grinblatt et al., 2008; Manski, 1993). In all 21 studies the effect sizes we report are partial effects from models using a multivariate framework (see Appendix C). Generally three broad types of controls are used in models, individual characteristics, physical characteristics and vehicle characteristics with notably some commonality within the type of social influence measured (see Appendix F). For example studies focussing on measuring the spatial effects of neighbourhood control for correlation between individuals living in the same neighbourhood. In almost half of the studies we meta-analyse (10 studies), only ' $\beta$ ' values are reported with a further remaining 11 studies reporting either multivariate logits/probits or chi2 statistics. This is not ideal in meta-analysis where first order bivariate relationships are preferred (Borenstein et al., 2009; Peterson and Brown, 2005). In using multivariate coefficients we therefore rely on partial effect sizes for social influence which by definition also capture the influence of any other predictor or control variables in the model (Hunter and Schmidt, 1990). In substituting these statistics for ' $\beta$ ' values we follow Peterson and Brown (2005) who show that ' $\beta$ ' and ' $r$ ' can be highly correlated. There are of course disadvantages in taking this approach, notably that effect sizes may be supressed by other stronger effects in the same model (Hunter and Schmidt, 1990). This would result in a lower estimate of overall social influence effect. To test for this sensitivity we measure the extent to which effect sizes vary between social influence types (where similar controls are utilised) and between study designs (which measure similar outcomes) (see Appendix F). We find no significant effects due to application of control variables but a significant design effect suggests effects sizes from studies framed as discrete choice experiments are suppressed downwards.

We also assume that all regression coefficients reported are standardised, even if this is not made clear in the study. Effect sizes for each study are therefore calculated using either betas and sample size, or odds ratios and standard errors, depending on which are reported (Peterson and Brown, 2005). According to Cohen (1992), for measures of ' $r$ ' an effect size around 0.10 is considered to be small, 0.30 medium and 0.50 large. For studies including more than one outcome measure, the 
average effect size is calculated to avoid double-counting participants. For example Baltas and Saridakis (2013) measure the social influence effects on preference valuations for three different conventional vehicles - we translate these three coefficients into one effect size based on an average. In all cases where we average across multiple effect sizes in one study, the averaged effects relate to the same type of social influence.

Study designs vary in terms of both data collection methods and analytical methods (see Appendix B). Consequently we use random effects modelling which assumes studies are not similar and allows for variation about the mean both within and between studies. In contrast, a fixed effects model assumes all studies are similar in design and variation about the mean is only between studies, which would not be appropriate for our analysis. For our modelling, we used Comprehensive MetaAnalysis (CMA) Version 2 software (Borenstein et al., 2009) to calculate average effect sizes and Stata V13 (Statacorp) to model heterogeneity.

To assess the homogeneity between studies, we report $Q$ and $I^{2}$ statistics (Higgins and Green, 2011). The $Q$ statistic is a measure of dispersion about the mean. Although its size is sensitive to sample size it is useful as a significance test and therefore $p$-values are also reported. The $I^{2}$ statistic partitions the total dispersion into i) that due to random differences between reported effect sizes and ii) that due to other differences between studies. The $I^{2}$ statistic lies within a range of $0-100 \%$ and most importantly it is not affected by sample size or the scale used to measure effects. In this respect it is the most reliable indicator of heterogeneity. Scores in the region of $0-40 \%$ would be interpreted as indicating minimal or non-existent heterogeneity whereas scores in the region of $75-100 \%$ indicate considerable heterogeneity. We also measure and report publication bias in accordance with Borenstein et al. (2009). This estimates the extent to which a much larger sample size of studies with non-significant findings would change the estimation of average effect size compared to our sample size $(n=21)$.

\subsection{Estimation of effect sizes for social influence type and other moderators}

We distinguished three different types of social influence from our literature review of empirical studies: (1) interpersonal communication (2) neighbourhood effect (3) social norms. Although none of the 43 studies we reviewed compared the size of these effects on vehicle choice, we are able to test whether they vary in terms of effect size within a meta-analysis framework. We therefore report separate effect sizes and $p$-values for each type of social influence. We then use a $Q$ statistic to evaluate whether the strength of each type differs significantly.

In evaluating social influence on vehicle choices we make the assumption that there are no differences in social influence effects between AFVs or conventional vehicles. However, we also test for moderating effects on social influence by vehicle type, with a null hypothesis of no moderation.

\subsection{Estimation of cultural variation in social influence effects between countries}

Within the final 21 studies used for meta-analysis, 11 different countries were sampled representing Western cultures ( 7 countries), Asian cultures ( 3 countries), and the Middle East ( 1 country) (see Table 2). National cultures connect individuals through enduring value systems (Inglehart and Baker, 2000; Liang and He, 2012). Social influence is transmitted through social ties and networks (interpersonal communication), the behaviour of referent groups living in physical proximity (neighbourhood effect), and common or approved behaviours (social norms). Each of these types of social influence will be shaped by more generally-held values and beliefs that characterise national cultures. 
A commonly-used approach for measuring national culture originally identified four inter-related dimensions (Hofstede, 2001) and has since been expanded to a fifth dimension (Minkov and Hofstede, 2012). Two of these five dimensions are closely related and are particularly relevant to examining cultural variation in social influence on consumer choice (see Appendix B) for further details).

The individualism-collectivism dimension distinguishes individualist cultures in which people strive for distinctive individual identity and prioritise looking after themselves and their immediate family, from collectivist cultures in which people are more likely to belong to groups which confer personal identity, and looking after each other in exchange for loyalty (Hofstede, 2001). There is some evidence to suggest the individualism-collectivism dimension explains variation in social influence effect sizes between countries. Van den Bulte and Stremersch (2004) used meta-analysis to examine cultural variation in social influence effect size for 75 consumer durable products adopted in 77 different countries. They found more closely-grouped collectivist cultures have a higher propensity to imitate the behaviour of others within their social networks compared to more individual statusoriented cultures.

The pragmatic-normative dimension distinguishes normative cultures (e.g., Ireland) which exhibit greater respect for the status quo, short term reward and reinforcing traditions, from pragmatic cultures (e.g., the Netherlands) which adapt traditions more easily in accordance with changing social and economic conditions (Minkov and Hofstede, 2012). The pragmatic-normative dimension measures both traditional values such as religious faith, national pride, responsibility to parents and living up to others expectations, but also willingness to adapt these values in the longer term in line with changing social and economic conditions. The pragmatic-normative dimension is relatively new and has not been tested as an explanation of cross-country differences in social influence. However, we expect more normative countries to exhibit stronger social influence effects.

To evaluate the moderating effects of cultural differences between countries we use metaregression (Harbord and Higgins, 2009). We identify the scores for each country in our sample on the scales measuring two dimensions of national culture: individualism-collectivism; pragmaticnormative. Country scores on these dimensions of national culture are measured using data from the World Values Survey, a cross-national time series survey covering 100 different countries from 1981 onwards. The scores for both scales are taken from Hofstede's cultural dimensions website (see http://geert-hofstede.com/countries.html). We then include the country scores in a regression on social influence effect size to test for moderation. Using a regression model allows us to control for other factors that might explain heterogeneity such as variations in study design or vehicle type.

\section{Results}

\subsection{Social influence effect on vehicle choice}

21 studies are included in the calculation of the average size of social influence effects on vehicle choice. Figure 1 displays a forest plot with effect sizes for each study, the overall effect size and accompanying statistics from the random effects model. All individual effect sizes are positive and all but two are significant at $|\mathrm{p}| \leq 0.05$. 


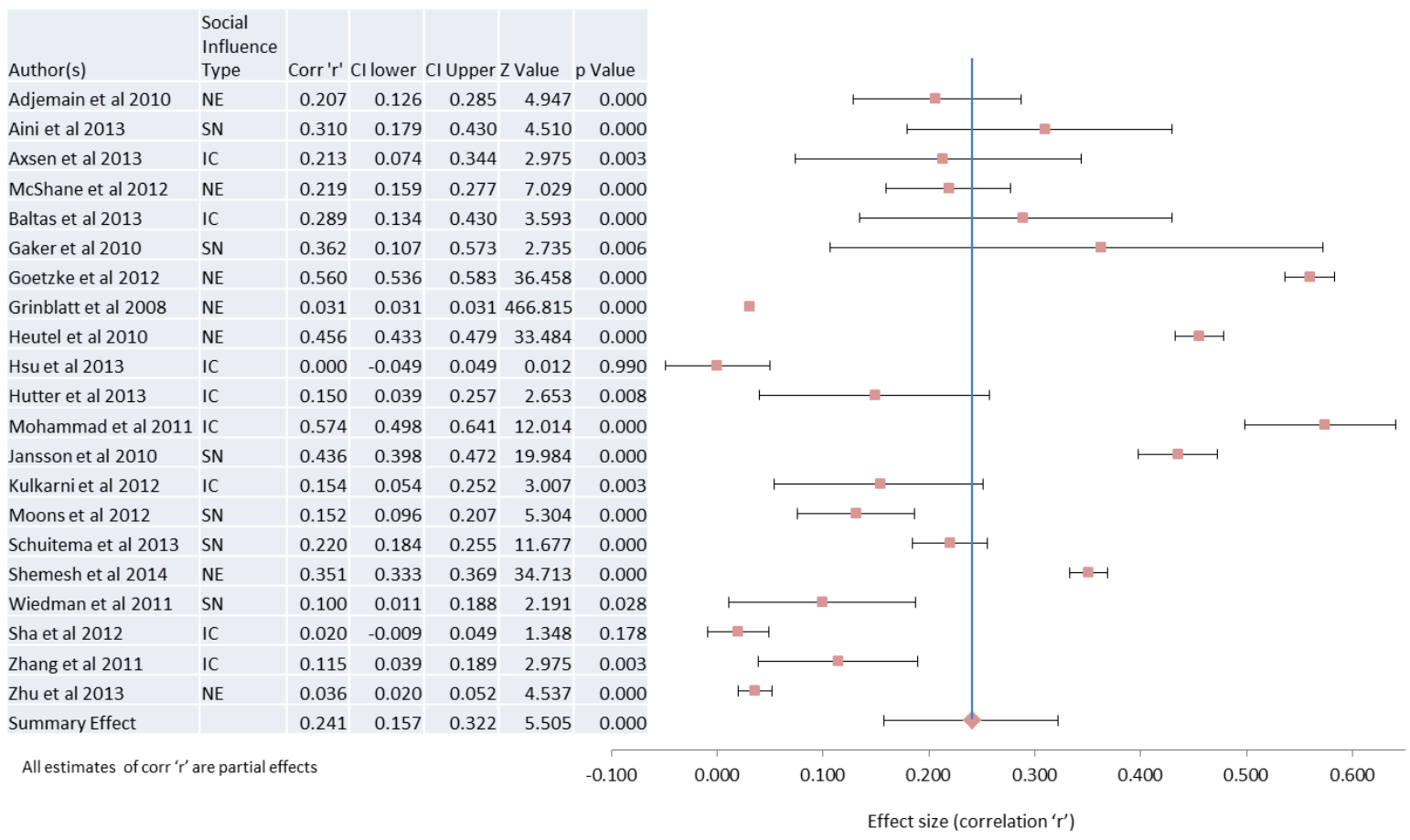

Figure 1 - Forest Plot of Social Influence Effect Sizes

Our meta-analysis of the 21 studies reveals an average effect size measured by the correlation coefficient ' $r$ ' of 0.241 ( $95 \% \mathrm{Cl}[0.157,0.322], Z=5.505,|p| \leq 0.000$ ) (see Table 3). This is shown by the vertical line in Figure 1 and is considered to be a small to medium effect in meta-analysis (Cohen, 1992). Significant heterogeneity is apparent across studies $(Q(20)=3904,|p| \leq 0.000)$. The $I^{2}$ value of 99.48 suggests that this is not accounted for by random variation but by systematic differences in effect size between studies. This heterogeneity can be seen in the forest plot (see Figure 1) where effect sizes vary between 0.02 (Sha et al., 2012) and 0.574 (Mohammad Reza and Neda, 2012).

In testing our results for publication bias we find that that no changes to the average effect size are required. Publication bias occurs when studies are omitted either because they report small or nonsignificant effect sizes (and are unpublished) or they are published in languages other than English. An initial test (Egger's regression intercept analysis) points to the possibility of this bias $(t(19)=3.36$, $|p| \leq 0.05$ ) but further investigation using a trim and fill analysis (Duval and Tweedie, 2000) suggests under the random effects assumptions used in our analysis, no adjustments are needed. Rosenthal's fail safe $\mathrm{N}$ provides a further sensitivity test and indicates that 4,156 studies with effect sizes of zero would have to be added to the sample to render the average effect size reported as non-significant. Given this finding we also infer that there is no bias introduced by using two studies which report insignificant effect sizes. Overall we infer that publication bias does not affect our findings.

\subsection{Social influence type and other moderators}

The effect size for each of the three social influence types is significant at $95 \%$ confidence level (see Table 3). For example the effect size of 0.278 for neighbourhood effect has a $p$-value of 0.000 . Although the neighbourhood effect size is stronger than interpersonal communication, the $Q$ statistic confirms that these effects are not significantly different from each other $(Q=0.9189(2), p-$ value $=0.6316$ ) and overall heterogeneity is not explained by grouping social influence effects into these three different types $\left(I^{2}=99.488\right)$. 
Table 3 - Main effect size and by type of social influence, vehicle, and study design

\begin{tabular}{|l|l|l|l|l|l|l|l|l|l|}
\hline & $\mathrm{N}$ & $\begin{array}{l}\text { Effect } \\
\text { Size, } \mathrm{r}\end{array}$ & $\begin{array}{l}\mathrm{Cl} \\
\text { Lower }\end{array}$ & $\begin{array}{l}\mathrm{Cl} \\
\text { Upper }\end{array}$ & $\begin{array}{l}\mathrm{z} \text { - } \\
\text { value }\end{array}$ & $\mathrm{p}$-value & Q-value (df) & $\begin{array}{l}\mathrm{p} \text { - } \\
\text { value }\end{array}$ & $\mathrm{I}^{2}$ \\
\hline Main effect & 21 & 0.241 & 0.157 & 0.322 & 5.505 & 0.000 & & & \\
\hline $\begin{array}{l}\text { by type of social } \\
\text { influence }\end{array}$ & & & & & & & & & \\
\hline $\begin{array}{l}\text { Interpersonal } \\
\text { communication }\end{array}$ & 8 & 0.197 & 0.083 & 0.305 & 3.375 & 0.000 & $137.832(7)$ & 0.000 & 94.921 \\
\hline $\begin{array}{l}\text { Neighbourhood } \\
\text { effect }\end{array}$ & 7 & 0.278 & 0.122 & 0.418 & 3.445 & 0.000 & $3252.733(6)$ & 0.000 & 99.815 \\
\hline Social norms & 6 & 0.260 & 0.135 & 0.376 & 4.031 & 0.000 & $108.128(5)$ & 0.000 & 95.376 \\
\hline by type of vehicle & 11 & 0.218 & 0.086 & 0.343 & 3.200 & 0.001 & $991.414(10)$ & 0.000 & 98.991 \\
\hline AFV & 10 & 0.267 & 0.117 & 0.405 & 3.430 & 0.001 & $2419.662(9)$ & 0.000 & 99.628 \\
\hline Conventional & & & & & & & & & \\
\hline by study design & 4 & 0.117 & 0.009 & 0.223 & 2.121 & 0.034 & $16.419(3)$ & 0.001 & 81.729 \\
\hline $\begin{array}{l}\text { discrete choice } \\
\text { experiments }\end{array}$ & 5 & 0.183 & 0.043 & 0.316 & 2.560 & 0.010 & $1210.115(4)$ & 0.000 & 99.669 \\
\hline logit regression & 12 & 0.295 & 0.220 & 0.336 & 7.445 & 0.000 & $321.692(11)$ & 0.000 & 96.581 \\
\hline $\begin{array}{l}\text { ordinary least } \\
\text { squares (OLS) } \\
\text { regression }\end{array}$ & & & & & & & & & \\
\hline
\end{tabular}

With respect to vehicle type we accept our null hypothesis that this is not a significant moderator $(Q=0.237(1), p$-value $=0.626)$. Social influence acts equally on conventional vehicles or AFVs (see Table 3). With respect to study design our selection of random effects modelling seems to be justifiable because there is significant heterogeneity which can be explained by including study design as a moderator $(Q=7.891(2), p$-value $=0.019)$. In other words differences in effect sizes are explainable by the specification of analytical models used in the empirical studies. We compare variation between discrete choice experiments (DCE) and those using other multivariate designs (including ordinary least squares (OLS) and ordinary logistic (logit) regression). The average effect size from DCE studies is smaller ( $r=0.117)$ than that from logit $(r=0.183)$ and OLS $(r=0.295)$ (see Table 3). We offer three possible explanations for this source of variation:

- OLS and logit models are sensitive to the effects of outliers which, if present within individual study samples, would systematically inflate average effect sizes (Bollen and Jackman, 1985).

- All OLS studies in the meta-analysis are based on a multivariate design which does not uniquely test the bivariate association between social influence and vehicle choice or ' $r$ '. Although Peterson and Brown (2005) confirm this is a valid approach, these beta coefficients are also explaining the effects of other moderators within the model and this might be inflating effect size.

- DCE studies in the meta-analysis are based on a fairly uniform design comparing consumers' utility between vehicle types based on a similar set of vehicle attributes (e.g., price, performance, body type). This emphasis on vehicle and monetary attributes may confound (weaken) any social influence effect observed (Wilson et al., 2014).

\subsection{Cultural differences between countries}

Our meta-regression model tests the moderating effects of national culture on social influence measured in 11 different countries. Because of the significance of study design in explaining variation between these studies, all regression models control for study design. We find Hofstede's individualism-collectivism dimension is not a significant moderator of social influence effect size 
$(\beta=0.0524$, s.e. $=0.17, Z=0.3,|p| \leq 0.76)$ and explains less than $2 \%$ of the variation in social influence effect size between countries (see Appendix $B$ for discussion). However we find the pragmaticnormative dimension is a significant moderator of social influence effect size $(\beta=-0.414$, s.e. $=0.13$, $\mathrm{Z}=-3,|\mathrm{p}| \leq 0.01)$. For every 1 standard deviation increase in a country's score on the scale measuring the pragmatic-normative dimension there is on average a $\beta=0.414$ decrease in the size of the social influence effect on vehicle choice (higher scores on the scale indicate more pragmatic national cultures). The adjusted R-squared value suggests that $33 \%$ of total between-study variation which is not due to random variation is explained by study design and by cultural differences between countries. The meta-regression model is a significant improvement on the baseline model $(F(3,17)=4.16$, Prob $>F=0.022)$.

When more than one covariate is included in a meta-regression there is an increased risk of a false positive (type I error). To account for this we run a permutation test (Higgins and Green, 2011) to calculate the true $\mathrm{p}$-value for the bivariate relationship between cultural differences and social influence effects on vehicle choice. This adjusted $p$-value is increased but remains significant at $95 \%$ level of confidence ( $p$-value $=0.046$ ). This finding confirms that the average social influence effect size of 0.241 identified in the meta-analysis varies according to the pragmatic-normative dimension of cultural difference between countries.

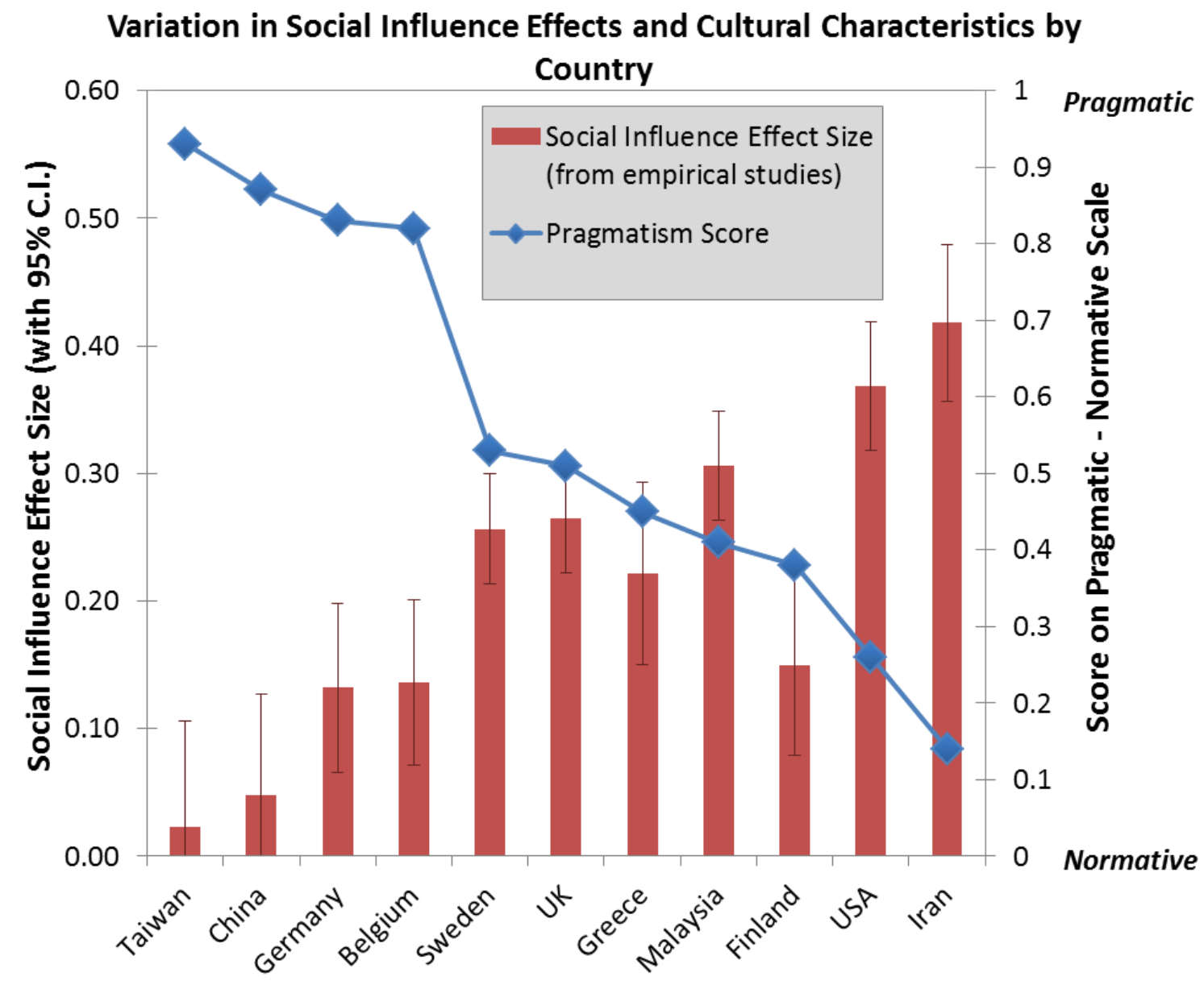

Figure 2 - Average Social Influence Effect Size for 11 Countries Included in Meta-Analysis Country scores on the pragmatic-normative scale are included for comparison (high score $=$ more pragmatic cultures). 
Figure 2 plots the average social influence effect size per country reported from our meta-regression model (red bars) against each country's score on the pragmatic-normative scale (blue line) (see Appendix E). Although the USA is an individualistic culture (as measured on the individualismcollectivism scale), it is also a more normative culture holding on more strongly to traditional values (with a score of 0.26 on the pragmatic-normative scale). The USA has a higher than average social influence effect size of $0.368(95 \% \mathrm{Cl}[0.287,0.469])$. In contrast China is a more collectivist culture but also more pragmatic (with a score of 0.87 on the pragmatic-normative scale). China has a lower than average social influence effect size of $0.047(95 \% \mathrm{Cl}[-0.028,0.204])$. These results are consistent with the Inglehart and Baker (2000) who find that USA is distinctive from other Western cultures in its adherence to important traditions. The pragmatic-normative scale reflects the tension between balancing these traditional values (and, indirectly, the influences of social norms) and willingness to adapt to rapid social and economic change over the longer term.Iran is the most strongly normative culture within our sample and has the highest average social influence effect size of $0.418(95 \% \mathrm{Cl}[0.345,0.540])$. Interpreting this finding within the context of our meta-analysis suggests that people in Iran are more likely to be influenced by social influence, whether interpersonal communication, neighbourhood effect, or social norms. One exception to the generally observed pattern in our findings (see Figure 2 ) is Finland which is a more normative culture but scores low on the average social influence effect size $(0.15095 \% \mathrm{Cl}[0.149,0.290]$. This finding reflects the variation in study designs and samples included in the meta-analysis. Finland's average social influence effect size is based on a single estimate of neighbourhood effect (Grinblatt et al., 2008). The Finland-based study is unique in its scale and design (large sample size, longitudinal data and inclusion of a temporal dimension to neighbourhood effect). This might account for a lower than expected estimate for Finland.

\section{Discussion}

In this paper we provide unique insight into social influence effects on vehicle choices. We answer two main questions: (1) Is there robust empirical evidence that social influence affects the vehicle choices of private users? (2) Does social influence vary between countries as a result of cultural differences?

With respect to our first question we find a significant small to medium effect size indicating that social influence is an important determinant of people's vehicle choices. When people are considering vehicle purchases they are influenced by the beliefs and behaviour of others around them. This is consistent with Abrahamse and Steg (2013) who found social influence effects exert a small to medium effect on resource conservation behaviours.

This small to moderate effect size is consistent with our expectations. Social influence is not expected to be a primary effect relative to for example vehicle price, availability, household income but it is, however, an important secondary effect. It explains residual variance and emphases the involvement of other people in car purchase decisions. It links to potential policy levers which could incentivise greater uptake of cleaner vehicle fuel technologies and it links to cross cultural differences. The small to moderate effect size we observe is likely to be a conservative estimate also, given that we used partial effect sizes used from all studies and likely to be confounded by other primary effects included in models (see Appendix F). 
Our analysis provides further evidence that the validity and reliability of research predicting vehicle choice is dependent on some representation of social influence effects within their design. In this respect we support the views put forward by Axsen et al. (2013) and Schuitema et al. (2013) who suggest that omitting social influence from the representation of vehicle purchase behaviour ignores the social, symbolic and cultural bases of these decisions.

Interestingly, however, we did not find any significant difference in the strength of the three types of social influence distinguished in the empirical literature: interpersonal communication, neighbourhood effect, and social norms. We offer two possible explanations. First, due to significant design differences between our sample of 21 studies, we used random effects modelling for our analysis as it exercises greater caution with respect to the reliability of the data. When we relax these assumptions using fixed effects we find social influence does differ significantly, with neighbourhood effect the strongest and interpersonal communication the weakest. With a greater number of studies measuring each type of social influence effect differences are more likely to have been observed. Second, the three types of social influence are distinct but related. For example, people are more likely to observe vehicles at close proximity such as within neighbourhoods or workplaces but they are also more likely to notice them when driven or owned by referent social groups. This interaction effect between neighbourhood effect and social norms is difficult to isolate in empirical studies (Goetzke and Weinberger, 2012; Grinblatt et al., 2008; McShane et al., 2012). Further research is needed to understand these interactions and so test the relative strength of different types of social influence. For the future we recommend researchers should utilise more innovative approaches to capturing social influence effects. Axsen et al. (2013) combine semistructured interviews with a stated choice experiment in which respondents rated the relative strength of different types of social influence. This work drew on the strengths of qualitative approaches to conceptualising and capturing perceptions and attitudes and then generalising them to a larger sample. Using an experimental design Gaker et al. (2010) used information cascade within laboratory conditions to test social norms of behaviour by observing people's behaviour. These are both good examples of using research design to capture a difficult construct. We also recommend researchers should utilise more the good quality social science data collected by many government surveys. For example UK Understanding Society and the USA's Panel Study of Income Dynamics both report geospatial and temporal data on peoples purchase patterns which lends itself well to studies which can isolate neighbourhood effects.

The significant effect of social influence on vehicle choice is also important for the transition to alternative fuel vehicles (AFVs) in line with climate change mitigation objectives (Helveston et al., 2015). Market penetration of AFVs is currently low. Our research suggests that market growth could occur more rapidly if people see more of their friends, families or work colleagues adopt AFVs as well as clearer evidence around them that AFVs are becoming more normal and acceptable. The effectiveness of strengthening elements of social influence could easily be tested as a means for stimulating low-carbon vehicle uptake. For example randomised trials could evaluate specific policy incentives such as vehicle demonstrations, trials and targeted subsidies for AFVs within neighbourhoods characterised by high observability of vehicle use (e.g., on street parking) and high social compatibility among referent groups (e.g., suburban neighbourhoods of similar socioeconomic status with high vehicle usage). Policy makers could also work with manufacturers and special interest groups to form communities of interest (including online communities) through which information exchange on AFVs can be supported.

However, based on available empirical studies, our analysis shows that the strength of social influence does not differ significantly between AFVs and conventional vehicles. Despite the visibility 
of AFVs (e.g., in terms of model, design, refuelling infrastructure), people are as likely to be influenced by the beliefs and behaviours of others regardless of what type of vehicle they are buying. On the one hand, policies that have worked to stimulate conventional vehicle purchases (e.g., by implying referent others have already purchased) are similarly likely to work for AFVs. On the other hand, new conventional vehicles (e.g., with high efficiency engines) will be stimulated by their own social influence mechanisms in competition with AFVs. Further research is needed to determine the implications on policy, particularly as AFVs diffuse more widely in the market as their price and performance attributes improve. There is clearly no 'one-size-fits-all' approach for harnessing social influence to increase the share of AFVs in the vehicle fleet.

With respect to our second research question we find countries vary significantly in their receptiveness to social influence. Cultural differences between countries measured by Hofstede's pragmatic-normative scale moderate the social influence effect size. This scale is based on measurements of social cohesion such as traditional values and family belief systems, but also of willingness to adapt these values to changing social conditions (Minkov and Hofstede, 2012). We find more normative countries are characterised by stronger social influence effects.

These cultural differences raise interesting questions for a global strategy to stimulate AFV adoption. Vehicle purchases in highly pragmatic cultures such as Sweden and the Netherlands may be less strongly culturally mediated, and so are conducive to policy experiments to support early adoption and improve functional attributes of AFVs. If resulting improvements in vehicle performance then spill over into countries with more normative cultures, social influence effects can help accelerate widespread diffusion.

Cultural differences between countries are also important for global analysis and modelling of AFV' potential contribution to climate change mitigation. Global energy-economy models typically assume that adoption propensities of more energy-efficient or low-carbon technologies are universally applicable (Laitner et al., 2000; Mundaca et al., 2010). Our findings provide quantitative measures of social influence effects that vary between countries. Moreover, global modelling tends to be informed by the more widely available empirical data from the USA as well as Europe. In line with Inglehart and Baker (2000), we find the USA to be exceptional among developed countries in having a much more traditional value system and higher receptiveness to social influence effects. It is noticeable in Figure 2 that the confidence intervals for the social influence effects for the USA and European countries do not overlap. This urges caution in generalising US empirical data to other regions in global models.

\section{Conclusions}

This paper provides the first meta-analysis of social influence effects on vehicle choice. Following a systematic review of the literature 43 studies are identified which measure these effects. Three social influence types are distinguished: interpersonal communication, neighbourhood effect, and social norms. A random effects meta-analysis with a sample of 21 comparable studies finds that social influence does explain vehicle choices. The overall effect size does not vary significantly between social influence types or between conventionally fuelled or AFV types. Although there is significant heterogeneity between studies, this is explained by differences between countries in terms of their intrinsic cultural receptiveness towards social influence effects. Our findings identify key challenges for vehicle choice research, policy, and modelling analysis, particularly with respect to AFVs. 
This work makes a valuable contribution to the field of social and spatial geography. It directly addresses the issue of improving the behavioural representation of global transport models which largely represent the diffusion of new vehicle technologies through a single representative agent lacking any social context (McCollum et al., 2016). It identifies a spatial element in terms of differences between country cultures in their receptiveness to social influence effects, highlighting the need for adapted planning and policy. It also informs global modelling and analysis with improved behavioural and social realism, with respect to the diffusion of novel technologies such as alternative fuel vehicles.

\section{References}

Abrahamse, W., Steg, L. (2013) Social influence approaches to encourage resource conservation: A meta-analysis. Global Environmental Change 23, 1773-1785.

Achtnicht, M., Bühler, G., Hermeling, C. (2012) The impact of fuel availability on demand for alternative-fuel vehicles. Transportation Research Part D: Transport and Environment 17, 262-269. Adjemian, M.K., Cynthia Lin, C.Y., Williams, J. (2010) Estimating spatial interdependence in automobile type choice with survey data. Transportation Research Part A: Policy and Practice 44, 661-675.

Aini, M.S., Chan, S.C., Syuhaily, O. (2013) Predictors of technical adoption and behavioural change to transport energy-saving measures in response to climate change. Energy Policy 61, 1055-1062. Axsen, J., Kurani, K.S. (2011) Interpersonal influence in the early plug-in hybrid market: Observing social interactions with an exploratory multi-method approach. Transportation Research Part D: Transport and Environment 16, 150-159.

Axsen, J., Kurani, K.S. (2012) Interpersonal influence within car buyers' social networks: applying five perspectives to plug-in hybrid vehicle drivers. Environment and Planning A 44, 1047-1065.

Axsen, J., Mountain, D.C., Jaccard, M. (2009) Combining stated and revealed choice research to simulate the neighbor effect: The case of hybrid-electric vehicles. Resource and Energy Economics 31, 221-238.

Axsen, J., Orlebar, C., Skippon, S. (2013) Social influence and consumer preference formation for proenvironmental technology: The case of a U.K. workplace electric-vehicle study. Ecological Economics 95, 96-107.

Baltas, G., Saridakis, C. (2013) An empirical investigation of the impact of behavioural and psychographic consumer characteristics on car preferences: An integrated model of car type choice. Transportation Research Part A: Policy and Practice 54, 92-110.

Banerjee, A.V. (1992) A simple model of herd behavior. Quarterly Journal of Economics 107, 797. Batley, R.P., Toner, J.P., Knight, M.J. (2004) A mixed logit model of U.K. household demand for alternative-fuel vehicles. International Journal of Transport Economics 31, 55-77.

Belgiawan, P.F., Schmöcker, J.D., Fujii, S. (2013) Effects of peer influence, satisfaction and regret on car purchase desire. Procedia Environmental Sciences 17, 485-493.

Bell, G.D. (1967) Self-confidence and persuasion in car buying. Journal of Marketing Research (JMR) 4, 46-52.

Beltramello, A., (2012) Market development for green cars, OECD Green Growth Papers, Paris. Bollen, K.A., Jackman, R.W. (1985) Regression diagnostics an expository treatment of outliers and influential cases. Sociological Methods \& Research 13, 510-542.

Borenstein, M.J., Hedges, L.V., Higgins, J.P., Rothstein, H.R. (2009) Introduction to meta-analysis. J Wiley \& Sons Ltd, Chichester.

Cialdini, R.B., Goldstein, N.J., (2004) Social influence: Compliance and conformity, Annual Review of Psychology, pp. 591-621. 
Cialdini, R.B., Kallgren, C.A., Reno, R.R., (1991) A focus theory of normative conduct: A theoretical refinement and reevaluation of the role of norms in human behavior, in: Mark, P.Z. (Ed.), Advances in Experimental Social Psychology. Academic Press, pp. 201-234.

Cialdini, R.B., Trost, M.R. (1998) Social influence: social norms, conformity and compliance. McGrawHill, New York.

Cohen, J. (1992) A power primer. Psychological bulletin 112, 155-159.

de Mooij, M., Hofstede, G. (2002) Convergence and divergence in consumer behavior: Implications for international retailing. Journal of Retailing 78, 61-69.

de Mooij, M., Hofstede, G. (2011) Cross-cultural consumer behavior: A review of research findings. Journal of International Consumer Marketing 23, 181-192.

Dijk, M., Kemp, R., Valkering, P. (2013) Incorporating social context and co-evolution in an innovation diffusion model-with an application to cleaner vehicles. Journal of Evolutionary Economics 23, 295329.

Donnelly Jr, J.H., Ivancevich, J.M. (1974) A methodology for identifying innovator characteristics of new brand purchasers. Journal of Marketing Research (JMR) 11, 331-334.

Duval, S., Tweedie, R. (2000) Trim and fill: A simple funnel-plot-based method of testing and adjusting for publication bias in meta-analysis. Biometrics 56, 455-463.

Eggers, F., Eggers, F. (2011) Where have all the flowers gone? Forecasting green trends in the automobile industry with a choice-based conjoint adoption model. Technological Forecasting and Social Change 78, 51-62.

Eppstein, M.J., Grover, D.K., Marshall, J.S., Rizzo, D.M. (2011) An agent-based model to study market penetration of plug-in hybrid electric vehicles. Energy Policy 39, 3789-3802.

Feng, J., Papatla, P. (2012) Is online word of mouth higher for new models or redesigns? An investigation of the automobile industry. Journal of Interactive Marketing 26, 92-101.

Figueroa, M., Lah, O., Fulton, L.M., McKinnon, A., Tiwari, G. (2014) Energy for transport. Annual Review of Environment and Resources 39, 295-325.

Gaker, D., Zheng, Y., Walker, J. (2010) Experimental economics in transportation: A focus on social influences and the provision of information. Transportation Research Record.

Gallez, C. (1994) Identifying the long term dynamics of car ownership: a demographic approach. Transport Reviews 14, 83-102.

Goetzke, F., Weinberger, R. (2012) Separating contextual from endogenous effects in automobile ownership models. Environment and Planning A 44, 1032-1046.

Gough, G., Oliver, S., Thomas, J. (2012) An introduction to systematic reviews. Sage London.

Graham-Rowe, E., Gardner, B., Abraham, C., Skippon, S., Dittmar, H., Hutchins, R., Stannard, J. (2012) Mainstream consumers driving plug-in battery-electric and plug-in hybrid electric cars: A qualitative analysis of responses and evaluations. Transportation Research Part A: Policy and Practice 46, 140153.

Granovetter, M. (1985) Economic action and social structure: The problem of embeddedness.

American Journal of Sociology 91, 481-510.

Granovetter, M.S. (1973) The strength of weak ties. American Journal of Sociology 78, 1360-1380.

Grinblatt, M., Keloharju, M., Ikäheimo, S. (2008) Social influence and consumption: Evidence from the automobile purchases of neighbors. Review of Economics and Statistics 90, 735-753.

Harbord, R., Higgins, J. (2009) Metareg: Stata module to perform meta-analysis regression. Statistical Software Components.

Heffetz, O. (2011) A Test of conspicuous consumption: Visibility and income elasticities. The Review of Economics and Statistics 93, 1101-1117.

Heffner, R.R., Kurani, K.S., Turrentine, T.S. (2007) Symbolism in California's early market for hybrid electric vehicles. Transportation Research Part D: Transport and Environment 12, 396-413. 
Helveston, J.P., Liu, Y., Feit, E.M., Fuchs, E., Klampfl, E., Michalek, J.J. (2015) Will subsidies drive electric vehicle adoption? Measuring consumer preferences in the U.S. and China. Transportation Research Part A: Policy and Practice 73, 96-112.

Heutel, G., Muehlegger, E., (2010) Consumer learning and hybrid vehicle adoption, Working Paper Series, Harvard Kennedy School.

Higgins, J., Green, S. (2011) Cochrane handbook for systematic reviews of interventions version 5.1.0. The Cochrane Collaboration.

Hofstede, G. (2001) Culture's consequences: International differences in work related values. Sage, Beverly Hills, CA.

Hsu, C.-I., Li, H.-C., Lu, S.-M. (2013) A dynamic marketing model for hybrid electric vehicles: A case study of Taiwan. Transportation Research Part D: Transport and Environment 20, 21-29.

Huétink, F.J., der Vooren, A.v., Alkemade, F. (2010) Initial infrastructure development strategies for the transition to sustainable mobility. Technological Forecasting and Social Change 77, 1270-1281. Hunter, J.E., Schmidt, F.L. (1990) Methods of Meta-Analysis: Correcting Error and Bias in Research Findings, Third Edition ed. Sage Newbury Park, CA.

Hutter, K., Hautz, J., Dennhardt, S., Füller, J. (2013) The impact of user interactions in social media on brand awareness and purchase intention: the case of MINI on Facebook. Journal of Product \& Brand Management 22, 342-351.

Inglehart, R., Baker, W.E. (2000) Modernization, cultural change, and the persistence of traditional values. American Sociological Review 65, 19-51.

Jackson, T., (2005) Motivating sustainable consumption: A reivew of evidence on consumer behaviour and behavioural change, Sustainable Development Research Network. University of Surrey, Guildford. Surrey.

Jansson, J., Marell, A., Nordlund, A. (2010) Green consumer behavior: determinants of curtailment and eco - innovation adoption. Journal of Consumer Marketing 27, 358-370.

Kim, H., Markus, H.R. (1999) Deviance or uniqueness, harmony or conformity? A cultural analysis. Journal of Personality and Social Psychology 77, 785-800.

Kim, H.S., Drolet, A. (2003) Choice and self-expression: A cultural analysis of variety-seeking. Journal of Personality and Social Psychology 85, 373-382.

Kim, S., Lee, K., Cho, J.K., Kim, C.O. (2011) Agent-based diffusion model for an automobile market with fuzzy TOPSIS-based product adoption process. Expert Systems with Applications 38, 7270-7276. Kulkarni, G., Ratchford, B.T., Kannan, P.K. (2012) The impact of online and offline information sources on automobile choice behavior. Journal of Interactive Marketing 26, 167-175.

Laitner, J.A.S., Decanio, S.J., Koomey, J.G., Sanstad, A.H., (2000) Incorporating behavioural, social and organisational phenomena in the assessment of climate change mitigation options, in: Jochem, E., Sathaye, J., Bouille, D. (Eds.), Society, Behaviour, and Climate change Mitigation. Kluwer Academic Publishers, Dordrecht, The Netherlands.

Lee, D.H., Park, S.Y., Kim, J.W., Lee, S.K. (2013) Analysis on the feedback effect for the diffusion of innovative technologies focusing on the green car. Technological Forecasting and Social Change 80, 498-509.

Liang, B., He, Y. (2012) The effect of culture on consumer choice: the need for conformity vs. the need for uniqueness. International Journal of Consumer Studies 36, 352-359.

Maness, M., Cirillo, C., Dugundji, E.R. (2015) Generalized behavioral framework for choice models of social influence: Behavioral and data concerns in travel behavior. Journal of Transport Geography 46, 137-150.

Manski, C.F. (1993) Identification of endogenous social effects: The reflection problem. The Review of Economic Studies 60, 531-542.

Mau, P., Eyzaguirre, J., Jaccard, M., Collins-Dodd, C., Tiedemann, K. (2008) The 'neighbor effect': Simulating dynamics in consumer preferences for new vehicle technologies. Ecological Economics 68, 504-516. 
McCollum, D., Wilson, C., Pettifor, H., Ramea, K., Krey, V., Riahi, K., Bertram, C., Lin, Z., Edelenbosch, O., Fujisawa, S. (2016) Improving the behavioural realism of global integrated assessment models: An application to consumers' vehicle choices. Transportation Research Part D: Transport and Environment Accepted for submission.

McShane, B.B., Bradlow, E.T., Berger, J. (2012) Visual influence and social groups. Journal of Marketing Research (JMR) 49, 854-871.

Metz, D. (2010) Saturation of demand for daily travel. Transport Reviews 30, 659-674.

Minkov, M., Hofstede, G. (2012) Hofstede's fifth dimension: New evidence from the World Values Survey. Journal of Cross-Cultural Psychology 43, 3-14.

Mohammad Reza, J., Neda, S. (2012) The effect of electronic word of mouth on brand image and purchase intention. Marketing Intelligence \& Planning 30, 460-476.

Moons, I., De Pelsmacker, P. (2012) Emotions as determinants of electric car usage intention. Journal of Marketing Management 28, 195-237.

Moreno-Munoz, A., Bellido-Outeirino, F.J., Siano, P., Gomez-Nieto, M.A. (2016) Mobile social media for smart grids customer engagement: Emerging trends and challenges. Renewable and Sustainable Energy Reviews 53, 1611-1616.

Mundaca, L., Neij, L., Worrell, E., McNeil, M. (2010) Evaluating energy efficiency policies with energyeconomy models. Annual Review of Environment and Resources 35, 305-344.

Murtaugh, M., Gladwin, H. (1980) A hierarchical decision-process model for forecasting automobile type-choice. Transportation Research Part A: General 14, 337-347.

Ozaki, R., Sevastyanova, K. (2011) Going hybrid: An analysis of consumer purchase motivations.

Energy Policy 39, 2217-2227.

Park, S.Y., Kim, J.W., Lee, D.H. (2011) Development of a market penetration forecasting model for Hydrogen Fuel Cell Vehicles considering infrastructure and cost reduction effects. Energy Policy 39, 3307-3315.

Peattie, K. (2010) Green consumption: Behavior and norms. Annual Review of Environment and Resources 35, 195-228.

Peres, R., Muller, E., Mahajan, V. (2010) Innovation diffusion and new product growth models: A critical review and research directions. International Journal of Research in Marketing 27, 91-106.

Peterson, R.A., Brown, S.P. (2005) On the use of beta coefficients in meta-analysis. Journal of Applied Psychology 90, 175-181.

Potoglou, D., Kanaroglou, P.S. (2008) Modelling car ownership in urban areas: a case study of Hamilton, Canada. Journal of Transport Geography 16, 42-54.

Rogers, E.M. (2003) Diffusion of Innovations. Free Press, New York.

Rosenthal, R., DiMatteo, M.R. (2001) Meta-analysis: Recent developments in quantitative methods for literature reviews. Annual Review of Psychology 52, 59-82.

Schuitema, G., Anable, J., Skippon, S., Kinnear, N. (2013) The role of instrumental, hedonic and symbolic attributes in the intention to adopt electric vehicles. Transportation Research Part A: Policy and Practice 48, 39-49.

Schwartz, S.H. (1994) Beyond individualism/collectivism: New cultural dimensions of values. Thousand Oaks, Sage, CA.

Sha, Y., Mantian, H., Winer, R.S., Assael, H., Xiaohong, C. (2012) An empirical study of word-of-mouth generation and consumption. Marketing Science 31, 952-963.

Shafiei, E., Thorkelsson, H., Ásgeirsson, E.I., Davidsdottir, B., Raberto, M., Stefansson, H. (2012) An agent-based modeling approach to predict the evolution of market share of electric vehicles: A case study from Iceland. Technological Forecasting and Social Change 79, 1638-1653.

Sharmeen, F., Arentze, T., Timmermans, H. (2014) Dynamics of face-to-face social interaction frequency: role of accessibility, urbanization, changes in geographical distance and path dependence. Journal of Transport Geography 34, 211-220. 
Shemesh, J., Zapatero, F., (2014) Thou shalt not covet thy (suburban) neighbour's car, 2011 annual meeting of the academy of behavioural finance \& economics.

Sims, R., Schaeffer, R., Creutzig, F., Cruz-Núñez, X., D’Agosto, M., Dimitriu, D., Figueroa Meza, M.J., Fulton, L., Kobayashi, S., Lah, O., McKinnon, A., Newman, P., Ouyang, M., Schauer, J.J., Sperling, D., Tiwari, G., (2014) Transport

in: Edenhofer, O., R. Pichs-Madruga, Y. Sokona, E. Farahani, S. Kadner, K. Seyboth, A. Adler,, I. Baum, S.B., P. Eickemeier, B. Kriemann, J. Savolainen, S. Schlömer, C. von Stechow, T. Zwickel and J.C. Minx (eds.). (Eds.), Climate Change Contribution of Working Group III to the Fifth Assessment Report of the Intergovernmental Panel on Climate Change. Cambridge University Press, Cambridge.

Sunitiyoso, Y., Avineri, E., Chatterjee, K. (2013) Dynamic modelling of travellers' social interactions and social learning. Journal of Transport Geography 31, 258-266.

Ting, Z., Gensler, S., Garcia, R. (2011) A Study of the diffusion of alternative fuel vehicles: An agentbased modeling approach. Journal of Product Innovation Management 28, 152-168.

Turcksin, L., Mairesse, O., Macharis, C. (2013) Private household demand for vehicles on alternative fuels and drive trains: a review. European Transport Research Review 5, 149-164.

Valente, T.W. (1996) Social network thresholds in the diffusion of innovations. Social Networks 18, 69-89.

Van den Bulte, C., Stremersch, S. (2004) Social contagion and income heterogeneity in new product diffusion: A meta-analytic test. Marketing Science 23, 530-544.

Wellman, B. (1988) Structural analysis: From method and metaphor to theory and substance.

Cambridge University Press, Cambridge.

Wiedmann, K.-P., Hennigs, N., Pankalla, L., Kassubek, M., Seegebarth, B. (2011) Adoption barriers and resistance to sustainable solutions in the automotive sector. Journal of Business Research 64 , 1201-1206.

Wilson, C., Pettifor, H., McCollum, D., (2014) Improving the behavioural realism of integrated assessment models of global climate change mitigation: a research agenda. ADVANCE Project Deliverable No.3.2. Tyndall Centre for Climate Change Research and International Institute for Applied Systems Analysis (IIASA), Laxenburg, Austria.

Yang, S., Allenby, G.M. (2003) Modeling interdependent consumer preferences. Journal of Marketing Research (JMR) 40, 282-294.

Young, H.P. (2009) Innovation diffusion in heterogeneous populations: Contagion, social influence, and social learning. American Economic Review 99, 1899-1924.

Zhang, Y., Yu, Y., Zou, B. (2011) Analyzing public awareness and acceptance of alternative fuel vehicles in China: The case of EV. Energy Policy 39, 7015-7024.

Zhu, X., Chao, L. (2013) Investigating the neighborhood effect on hybrid vehicle adoption.

Transportation Research Record: Journal of the Transportation Research Board, 37-44. 
Appendix A - Systematic Literature Review

Inclusion criteria

Our first requirement was to identify empirical research which tested mechanisms of social influence on vehicle choices and use this to provide a framing for the study. By 'vehicle choices' we include ownership, purchase and adoption decisions, as well as their precursor intentions and motivations. Within vehicle choices we include both conventionally fuelled petrol (gasoline) and diesel vehicles and AFVs (including electric vehicles, plug in hybrid electric vehicles, LPG, biofuel and hydrogen fuel cell). A systematic review identified only 72 studies, the majority of which $(n=66)$ came from published sources. Of these 72 studies 43 met our initial inclusion criteria:

- Study is grounded in empirical data;

- Study is based on a sample drawn from a population of car owners, car drivers, or people of driving age;

- Study explores the relationship between social influence (as conceptualised within this study) and vehicle choice (including ownership) as either a main or partial effect:

o includes studies of where social status attached to vehicle ownership is examined, but excludes studies where these are embedded within brand attributes as these are specific to a product;

○ includes studies of built environment characteristics typically used to measure neighbourhood effects.

\section{Search strategy}

We used multiple alternative search terms for vehicle choice including: "vehicle", "automobile", "car", and "choice", "purchase", "decision", "ownership", "preference". To capture studies measuring the effect of social influence we use multiple alternative phrases within Boolean search terms: "social influence*" OR "social norm*" OR "social network*", "neighb*effect" OR "peer effect" OR "peer influence*", "media" OR "information", "diffusion" OR "social innovation", "social groups", "behav* norms", "behav* routines", "social risk", "social media", "word of mouth", "social herding", "social conformity", "personal norms", "social symbol", "social signal".

We applied our search terms to Science Direct, Scopus, EBSCO and PsyARTICLES as well as the websites of relevant journals not included in these databases. To minimise possible publication bias in peer-reviewed journals towards studies reporting larger and significant effect sizes, we also included grey literature accessed through wider search engines such as Google Scholar.

Data extraction

Of the 43 studies identified only 2 came from grey literature. A standardised coding procedure was followed to extract data from each study: author(s), publication year, date and location of data collection, methodological approach (quantitative, qualitative, mixed method), outcome measures, measure of behavioural antecedents (including social influence and other demographic and psychographic constructs and/or controls), sample size, particular design characteristics (type of 
data including longitudinal, time series, narrative), data analysis, methods and key findings. For quantitative studies, modelling approach was recorded and studies identified that had comparative statistics needed to calculate effect sizes within the meta-analysis, including beta coefficients, logit/probit coefficients, chi-square statistics, standard errors, t-test and p-values (one-sided) (see Appendix D for details of all 43 studies). 
Appendix B - Cultural Variation in Social Influence Effects

Various frameworks have been developed to measure national cultural characteristics or generallyheld values (Inglehart and Baker, 2000; Schwartz, 1994). One of the most popular and widely tested is Hofstede's dimensions of national culture (Hofstede, 2001). This originally identified 4 dimensions of national culture:

\begin{tabular}{|l|l|}
\hline Cultural dimension & Description \\
\hline Power distance (PD) & $\begin{array}{l}\text { The extent to which broad inequalities of power are accepted within } \\
\text { society. People in high PD cultures accept they have a rightful place } \\
\text { in the social hierarchy and status reflects this position. }\end{array}$ \\
\hline $\begin{array}{l}\text { Individualism versus } \\
\text { Collectivism (IDV) }\end{array}$ & $\begin{array}{l}\text { In individualist cultures people strive for individual identity making } \\
\text { them distinctive from others. They prioritise looking after } \\
\text { themselves and their immediate family. In collectivist cultures } \\
\text { people are more likely to belong to groups, looking after each other } \\
\text { in exchange for loyalty. Personal identity comes from the social } \\
\text { network to which one belongs. }\end{array}$ \\
\hline $\begin{array}{l}\text { Masculinity versus } \\
\text { femininity (MAS) }\end{array}$ & $\begin{array}{l}\text { In masculine cultures dominant values are achievement and success } \\
\text { demonstrated by personal status. In feminine cultures caring for } \\
\text { others and quality of life are more important. In countries that score } \\
\text { high in MAS men and women have clearly identified roles. }\end{array}$ \\
\hline $\begin{array}{l}\text { Uncertainty Avoidance } \\
\text { (UA) }\end{array}$ & $\begin{array}{l}\text { The extent to which people feel threatened by uncertainty and } \\
\text { ambiguity. In high UA cultures there is a greater need for rules, } \\
\text { formal structures, hierarchies and belief in experts. }\end{array}$ \\
\hline
\end{tabular}

Hofstede's original four dimensional framework has been extended into a fifth cultural dimension, referred to as pragmatic-normative (or also long term-short term orientation) (Hofstede \& Minkov, 2010). Whilst closely related to individualism-collectivism in that it measures traditional values such as religious faith, divorce, national pride, responsibility to parents and living up to others expectations it also measures willingness to adapt these in the longer term in line with a changing social context. In effect it measures the extent to which countries value the past as opposed to looking towards the present or the future (Minkov and Hofstede, 2012). Countries which are more short term or normative in their thinking (e.g., Ireland) exhibit greater respect for the status quo, short term reward and reinforcing traditions, whereas more pragmatic countries (e.g., the Netherlands) show an ability to adapt traditions easily in accordance with changed conditions (Minkov and Hofstede, 2012).

Between-country differences in consumer choices due to cultural variation is confirmed by empirical studies (de Mooij and Hofstede, 2002; Kim and Markus, 1999; Kim and Drolet, 2003). As generalisations, people living in Westernised cultures are more individualistic, purchasing products which identify them as distinctive and independent from the choices of others. In contrast, East Asians from a more traditional and collectivist culture have a higher degree of conformity as they seek approval from others and generally conform to wider social norms (Kim and Markus, 1999; Kim and Drolet, 2003). Liang and He (2012), however, have shown that this generalisation between Western and East Asian cultures does not apply to all innovations, and that for products with a high degree of risk, consumers prefer known brands.

With respect to social influenceon purchases choices there is some evidence to suggest Hofstede's framework explains variation in social influence effect sizes between countries. Van den Bulte and Stremersch (2004) used meta-analysis to examine cultural variation in social influence effect size for 
75 consumer durable products adopted in 77 different countries. Applying these four dimensions they found more closely-grouped collectivist cultures have a higher propensity to imitate the behaviour of others within their social networks compared to more individual status-oriented cultures. In our meta-regression, we find a non-significant, small but positive coefficient for the individualism-collectivism scale which suggests social influence on vehicle choices increases as societies become more individualistic. A possible explanation is that close social networks (friends and family) are prioritised within individualistic cultures, and our literature review shows these close networks are important social mechanisms acting on vehicle choice.

The additional fifth pragmatic-normative dimension has not yet been tested in empirical research measuring social influence, but it is relevant for measuring changing values within modernising economies such as China and India where rapid changes in income and population are affecting the value basis of consumer decision-making (Inglehart and Baker, 2000; de Mooij and Hofstede, 2002). In particular, China is rapidly developing culturally as well as economically, with more wealthy consumers who are making purchase decisions informed by issues such as perceived risk and individual identity (Inglehart and Baker, 2000). 
Appendix C - Variation in Design of Quantitative Studies Measuring Social Influence (included in the meta-analysis, $\mathrm{n}=21$ )

\begin{tabular}{|c|c|c|c|}
\hline Author(s) & $\begin{array}{l}\text { Type of social } \\
\text { influence }\end{array}$ & Data collection method & Model type/Estimation method \\
\hline $\begin{array}{l}\text { Axsen et al. } \\
(2013)\end{array}$ & $\begin{array}{l}\text { Interpersonal } \\
\text { communication }\end{array}$ & $\begin{array}{l}\text { Discrete choice experiment with } \\
\text { participant rating of social interaction } \\
\text { effect }\end{array}$ & Multinomial logit model \\
\hline $\begin{array}{l}\text { Baltas and } \\
\text { Saridakis } \\
(2013) \\
\end{array}$ & $\begin{array}{l}\text { Interpersonal } \\
\text { communication }\end{array}$ & Discrete choice experiment & Multinomial logit model \\
\hline $\begin{array}{l}\text { Hsu et al. } \\
(2013)\end{array}$ & $\begin{array}{l}\text { Interpersonal } \\
\text { communication }\end{array}$ & Discrete choice experiment & Multinomial logit model \\
\hline $\begin{array}{l}\text { Hutter et al. } \\
(2013))\end{array}$ & $\begin{array}{l}\text { Interpersonal } \\
\text { communication }\end{array}$ & $\begin{array}{l}\text { Link to online questionnaire through } \\
\text { posting on MINI facebook brand page }\end{array}$ & $\begin{array}{l}\text { Structural equation model based on } \\
\text { ordinary least squares linear } \\
\text { regression }\end{array}$ \\
\hline $\begin{array}{l}\text { Kulkarni et al. } \\
\text { (2012) }\end{array}$ & $\begin{array}{l}\text { Interpersonal } \\
\text { communication }\end{array}$ & Discrete choice experiment & Multinomial logit model \\
\hline $\begin{array}{l}\text { Mohammad } \\
\text { Reza and } \\
\text { Neda (2012) }\end{array}$ & $\begin{array}{l}\text { Interpersonal } \\
\text { communication }\end{array}$ & Survey & $\begin{array}{l}\text { Structural equation model based on } \\
\text { ordinary least squares linear } \\
\text { regression }\end{array}$ \\
\hline $\begin{array}{l}\text { Sha et al. } \\
(2012)\end{array}$ & $\begin{array}{l}\text { Interpersonal } \\
\text { communication }\end{array}$ & Secondary data - UK consumer survey & Bivariate probit model \\
\hline $\begin{array}{l}\text { Zhang et al. } \\
\text { (2011) }\end{array}$ & $\begin{array}{l}\text { Interpersonal } \\
\text { communication }\end{array}$ & Discrete choice experiment & Multinomial logit model \\
\hline $\begin{array}{l}\text { Adjemian et } \\
\text { al. (2010) }\end{array}$ & $\begin{array}{l}\text { Neighbourhood } \\
\text { effect }\end{array}$ & Secondary data source - travel survey & $\begin{array}{l}\text { Spatial regression model using } \\
\text { 'Moran's I' to measure spatial } \\
\text { autocorrelation }\end{array}$ \\
\hline $\begin{array}{l}\text { Goetzke and } \\
\text { Weinberger } \\
\text { (2012) }\end{array}$ & $\begin{array}{l}\text { Neighbourhood } \\
\text { effect }\end{array}$ & $\begin{array}{l}\text { Secondary data - New York Metropolitan } \\
\text { Council Regional Transportation Interview } \\
\text { Survey (2004) combined with Census data }\end{array}$ & $\begin{array}{l}\text { Binary probit using two-step } \\
\text { conditional maximum likelihood } \\
\text { estimation (includes instrumental } \\
\text { variables to control for endogeneity) }\end{array}$ \\
\hline $\begin{array}{l}\text { Grinblatt et } \\
\text { al. (2008) }\end{array}$ & $\begin{array}{l}\text { Neighbourhood } \\
\text { effect }\end{array}$ & $\begin{array}{l}\text { Experimental design in which influence of } \\
\text { ten nearest neighbours is compared to the } \\
\text { influences of the forty next nearest } \\
\text { neighbours testing the hypothesis that the } \\
\text { closer people live the more influence they } \\
\text { have }\end{array}$ & $\begin{array}{l}\text { Pooled time series and cross } \\
\text { sectional regression }\end{array}$ \\
\hline $\begin{array}{l}\text { Heutel and } \\
\text { Muehlegger } \\
\text { (2010) }\end{array}$ & $\begin{array}{l}\text { Neighbourhood } \\
\text { effect }\end{array}$ & $\begin{array}{l}\text { Simulation using data set purchased from } \\
\text { JD Power and Associates (proprietary data } \\
\text { on consumer purchases of new vehicles) } \\
\text { for } 11 \text { hybrid models. This is combined } \\
\text { with current population survey data }\end{array}$ & $\begin{array}{l}\text { Fixed effects panel regression (Hutter } \\
\text { et al., 2013)n model }\end{array}$ \\
\hline $\begin{array}{l}\text { McShane et } \\
\text { al. (2012) }\end{array}$ & $\begin{array}{l}\text { Neighbourhood } \\
\text { effect }\end{array}$ & $\begin{array}{l}\text { Secondary data source - USA dealerships } \\
\text { (JD Power and Associates Power } \\
\text { Information Network (PIN) }\end{array}$ & $\begin{array}{l}\text { Hierarchical Bayesian probability } \\
\text { model reporting logistic forms }\end{array}$ \\
\hline $\begin{array}{l}\text { Shemesh and } \\
\text { Zapatero } \\
(2014)\end{array}$ & $\begin{array}{l}\text { Neighbourhood } \\
\text { effect }\end{array}$ & $\begin{array}{l}\text { Secondary data on vehicle purchases from } \\
\text { three counties of Southern California } \\
\text { combined with census block group which is } \\
\text { more detailed than ZIP codes }\end{array}$ & $\begin{array}{l}\text { Ordinary least squares linear } \\
\text { regression }\end{array}$ \\
\hline $\begin{array}{l}\text { Zhu and Chao } \\
\text { (2013) }\end{array}$ & $\begin{array}{l}\text { Neighbourhood } \\
\text { effect }\end{array}$ & $\begin{array}{l}\text { Florida } 2009 \text { Household Travel Survey with } \\
\text { Florida add on data }\end{array}$ & $\begin{array}{l}\text { Cluster analysis followed by binary } \\
\text { logit model }\end{array}$ \\
\hline $\begin{array}{l}\text { Aini et al. } \\
(2013)\end{array}$ & Social Norms & Survey & $\begin{array}{l}\text { Ordinary least squares linear } \\
\text { regression }\end{array}$ \\
\hline $\begin{array}{l}\text { Gaker et al. } \\
(2010)\end{array}$ & Social Norms & $\begin{array}{l}\text { Information cascade experiment in which } \\
\text { subjects make decisions in pre-determined } \\
\text { order and their choices are broadcast to } \\
\text { decision makers who follow. Everyone but } \\
\text { the first subject knows the decision of } \\
\text { some of the other people in the }\end{array}$ & Multinomial logit model \\
\hline
\end{tabular}




\begin{tabular}{|l|l|l|l|}
\hline & & experiment. & \\
\hline $\begin{array}{l}\text { Jansson et al. } \\
(2010)\end{array}$ & Social Norms & Survey & $\begin{array}{l}\text { Principle components analysis } \\
\text { followed by stepwise regression }\end{array}$ \\
\hline $\begin{array}{l}\text { Moons and } \\
\text { Pe } \\
\begin{array}{l}\text { Pelsmacker } \\
(2012)\end{array}\end{array}$ & Social Norms & Online survey using snowball sampling & $\begin{array}{l}\text { Repeated measures ANOVA and } \\
\text { Ordinary least squares linear } \\
\text { regression }\end{array}$ \\
\hline $\begin{array}{l}\text { Schuitema et } \\
\text { al. (2013) }\end{array}$ & Social Norms & Repeated measures online survey & $\begin{array}{l}\text { Ordinary least squares linear } \\
\text { regression }\end{array}$ \\
\hline $\begin{array}{l}\text { Wiedmann et } \\
\text { al. (2011) }\end{array}$ & Social Norms & $\begin{array}{l}\text { Internet based survey through large } \\
\text { automotive company (snowball sampling } \\
\text { method) car owners who hesitate to buy } \\
\text { NGV }\end{array}$ & $\begin{array}{l}\text { Path analysis reporting beta } \\
\text { coefficients }\end{array}$ \\
\hline
\end{tabular}


Appendix D - Empirical Studies of Social Influence on Vehicle Choice (identified in systematic literature review, $n=43$ )

\begin{tabular}{|c|c|c|c|c|c|c|}
\hline Author(s) & Country & $\begin{array}{l}\text { Type of social } \\
\text { influence }\end{array}$ & Target group & $\mathrm{N}$ & Outcome measure & $\begin{array}{l}\text { Comparable } \\
\text { quant effect } \\
\text { size? }\end{array}$ \\
\hline $\begin{array}{l}\text { Axsen et al. } \\
\text { (2013) }\end{array}$ & UK & $\begin{array}{l}\text { Interpersonal } \\
\text { communication }\end{array}$ & Workplace staff & 170 & $\begin{array}{l}\text { Vehicle choice between } \\
\text { AFV and conventional } \\
\text { vehicle given } \\
\text { interactions with co- } \\
\text { workers }\end{array}$ & Yes \\
\hline $\begin{array}{l}\text { Axsen and } \\
\text { Kurani (2012) }\end{array}$ & USA & $\begin{array}{l}\text { Interpersonal } \\
\text { communication }\end{array}$ & $\begin{array}{l}\text { AFV trial } \\
\text { participants }\end{array}$ & 40 & Perceptions of AFV & No \\
\hline $\begin{array}{l}\text { Axsen and } \\
\text { Kurani (2011) }\end{array}$ & USA & $\begin{array}{l}\text { Interpersonal } \\
\text { communication }\end{array}$ & $\begin{array}{l}\text { AFV trial } \\
\text { participants }\end{array}$ & 50 & $\begin{array}{l}\text { Ranked social influence } \\
\text { effect on perceptions of } \\
\text { AFV }\end{array}$ & No \\
\hline $\begin{array}{l}\text { Baltas and } \\
\text { Saridakis } \\
\text { (2013) }\end{array}$ & Greece & $\begin{array}{l}\text { Interpersonal } \\
\text { communication }\end{array}$ & Car drivers & 1,357 & $\begin{array}{l}\text { Choice between } 12 \\
\text { alternative cars given } \\
\text { pre-purchase } \\
\text { information from } \\
\text { friends and family. }\end{array}$ & Yes \\
\hline $\begin{array}{l}\text { Belgiawan et } \\
\text { al. (2013) }\end{array}$ & Indonesia & $\begin{array}{l}\text { Interpersonal } \\
\text { communication }\end{array}$ & Students & 134 & $\begin{array}{l}\text { Relative assessment of } \\
\text { social influence effects }\end{array}$ & No \\
\hline Bell (1967) & USA & $\begin{array}{l}\text { Interpersonal } \\
\text { communication }\end{array}$ & $\begin{array}{l}\text { Vehicle } \\
\text { purchasers }\end{array}$ & 234 & $\begin{array}{l}\text { Self-confidence in } \\
\text { making purchase } \\
\text { decision }\end{array}$ & No \\
\hline $\begin{array}{l}\text { Eppstein et } \\
\text { al. (2011) }\end{array}$ & USA & $\begin{array}{l}\text { Interpersonal } \\
\text { communication }\end{array}$ & $\begin{array}{l}\text { Simulation groun } \\
\text { macro-economic }\end{array}$ & $\begin{array}{l}\text { ed in } \\
\text { data }\end{array}$ & AFV market growth & No \\
\hline $\begin{array}{l}\text { Feng and } \\
\text { Papatla } \\
(2012) \\
\end{array}$ & USA & $\begin{array}{l}\text { Interpersonal } \\
\text { networks }\end{array}$ & $\begin{array}{l}\text { Consumer on- } \\
\text { line ratings }\end{array}$ & 616 & Vehicle ratings & No \\
\hline $\begin{array}{l}\text { Heffner et al. } \\
(2007)\end{array}$ & USA & $\begin{array}{l}\text { Interpersonal } \\
\text { communication }\end{array}$ & Households & 25 & $\begin{array}{l}\text { Personal stories related } \\
\text { to purchase of AFV }\end{array}$ & No \\
\hline $\begin{array}{l}\text { Hsu et al. } \\
\text { (2013) }\end{array}$ & Taiwan & $\begin{array}{l}\text { Interpersonal } \\
\text { communication }\end{array}$ & $\begin{array}{l}\text { Car owners and } \\
\text { non-car owners }\end{array}$ & 1,594 & $\begin{array}{l}\text { Choice between } \\
\text { vehicles given level of } \\
\text { influence from media }\end{array}$ & Yes \\
\hline $\begin{array}{l}\text { Hutter et al. } \\
(2013))\end{array}$ & Germany & $\begin{array}{l}\text { Interpersonal } \\
\text { communication }\end{array}$ & $\begin{array}{l}\text { Potential } \\
\text { customers of } \\
\text { specific } \\
\text { make/model }\end{array}$ & 311 & $\begin{array}{l}\text { Purchase intention as a } \\
\text { function of word of } \\
\text { mouth }\end{array}$ & Yes \\
\hline $\begin{array}{l}\text { Kulkarni et al. } \\
\text { (2012) }\end{array}$ & USA & $\begin{array}{l}\text { Interpersonal } \\
\text { communication }\end{array}$ & $\begin{array}{l}\text { Buyers of family } \\
\text { sedans }\end{array}$ & 886 & $\begin{array}{l}\text { Choice between } 24 \\
\text { family cars as a function } \\
\text { of internet use }\end{array}$ & Yes \\
\hline $\begin{array}{l}\text { Mohammad } \\
\text { Reza and } \\
\text { Neda (2012) }\end{array}$ & Iran & $\begin{array}{l}\text { Interpersonal } \\
\text { communication }\end{array}$ & $\begin{array}{l}\text { Potential } \\
\text { customers of } \\
\text { specific } \\
\text { make/model }\end{array}$ & 341 & $\begin{array}{l}\text { Purchase intention as a } \\
\text { function of word of } \\
\text { mouth }\end{array}$ & Yes \\
\hline $\begin{array}{l}\text { Sha et al. } \\
\text { (2012) }\end{array}$ & UK & $\begin{array}{l}\text { Interpersonal } \\
\text { communication }\end{array}$ & $\begin{array}{l}\text { Purchasers of } \\
\text { new vehicle }\end{array}$ & 4,544 & $\begin{array}{l}\text { Car ownership and } \\
\text { propensity to use word } \\
\text { of mouth }\end{array}$ & Yes \\
\hline $\begin{array}{l}\text { Shafiei et al. } \\
\text { (2012) }\end{array}$ & Iceland & $\begin{array}{l}\text { Interpersonal } \\
\text { communication }\end{array}$ & \multicolumn{2}{|c|}{$\begin{array}{l}\text { Simulation between agents } \\
\text { as consumers and vehicle } \\
\text { attributes }\end{array}$} & $\begin{array}{l}\text { Choices between } \\
\text { conventional and AFVs }\end{array}$ & No \\
\hline $\begin{array}{l}\text { Ting et al. } \\
(2011)\end{array}$ & USA & $\begin{array}{l}\text { Interpersonal } \\
\text { communication }\end{array}$ & \multicolumn{2}{|c|}{7000 agent interactions } & Vehicle choice & No \\
\hline $\begin{array}{l}\text { Zhang et al. } \\
\text { (2011) }\end{array}$ & China & $\begin{array}{l}\text { Interpersonal } \\
\text { communication }\end{array}$ & $\begin{array}{l}\text { Driving school } \\
\text { pupils }\end{array}$ & 299 & $\begin{array}{l}\text { Willingness to adopt } \\
\text { AFV as function of peer } \\
\text { effects }\end{array}$ & Yes \\
\hline $\begin{array}{l}\text { Adjemian et } \\
\text { al. (2010) }\end{array}$ & USA & $\begin{array}{l}\text { Neighbourhood } \\
\text { effect }\end{array}$ & $\begin{array}{l}\text { Households in } \\
\text { given census }\end{array}$ & 560 & $\begin{array}{l}\text { Purchase of specific car } \\
\text { body type given }\end{array}$ & Yes \\
\hline
\end{tabular}




\begin{tabular}{|c|c|c|c|c|c|c|}
\hline & & & region & & $\begin{array}{l}\text { behaviour of others in } \\
\text { the same } \\
\text { neighbourhood }\end{array}$ & \\
\hline $\begin{array}{l}\text { Goetzke and } \\
\text { Weinberger } \\
(2012)\end{array}$ & USA & $\begin{array}{l}\text { Neighbourhood } \\
\text { effects }\end{array}$ & $\begin{array}{l}\text { People who } \\
\text { would buy small } \\
\text { vehicle }\end{array}$ & 3,322 & $\begin{array}{l}\text { Car ownership as a } \\
\text { function of } \\
\text { characteristics of the } \\
\text { neighbourhood }\end{array}$ & Yes \\
\hline $\begin{array}{l}\text { Grinblatt et } \\
\text { al. (2008) }\end{array}$ & Finland & $\begin{array}{l}\text { Neighbourhood } \\
\text { effects }\end{array}$ & $\begin{array}{l}\text { Purchasers of } \\
\text { new vehicle }\end{array}$ & 211,173 & $\begin{array}{l}\text { Car purchase as a } \\
\text { function of purchases } \\
\text { of near neighbours }\end{array}$ & Yes \\
\hline $\begin{array}{l}\text { Heffetz } \\
(2011)\end{array}$ & USA & $\begin{array}{l}\text { Neighbourhood } \\
\text { effects }\end{array}$ & $\begin{array}{l}\text { Vehicle } \\
\text { purchasers }\end{array}$ & 480 & $\begin{array}{l}\text { Purchase of new or } \\
\text { used conventional } \\
\text { vehicle }\end{array}$ & No \\
\hline $\begin{array}{l}\text { Heutel and } \\
\text { Muehlegger } \\
(2010)\end{array}$ & USA & $\begin{array}{l}\text { Neighbourhood } \\
\text { effects }\end{array}$ & $\begin{array}{l}\text { Purchasers of } \\
\text { new vehicle }\end{array}$ & 4,630 & $\begin{array}{l}\text { AFV sales in given state } \\
\text { as a function of } \\
\text { increased social } \\
\text { signalling }\end{array}$ & Yes \\
\hline $\begin{array}{l}\text { Kim et al. } \\
(2011)\end{array}$ & Korea & $\begin{array}{l}\text { Neighbourhood } \\
\text { effect }\end{array}$ & \multicolumn{2}{|c|}{$\begin{array}{l}\text { Calibration experiment } \\
\text { simulating diffusion of } 3 \\
\text { vehicles within Korean car } \\
\text { market }\end{array}$} & $\begin{array}{l}\text { Mean market share } \\
\text { error (difference } \\
\text { between actual and } \\
\text { modelled data) }\end{array}$ & No \\
\hline $\begin{array}{l}\text { McShane et } \\
\text { al. (2012) }\end{array}$ & USA & $\begin{array}{l}\text { Neighbourhood } \\
\text { effect }\end{array}$ & $\begin{array}{l}\text { Purchasers of } \\
\text { new vehicle }\end{array}$ & 1,000 & $\begin{array}{l}\text { Car purchase behaviour } \\
\text { based on within } \\
\text { eyeshot purchases of } \\
\text { near neighbours }\end{array}$ & Yes \\
\hline $\begin{array}{l}\text { Shemesh and } \\
\text { Zapatero } \\
(2014)\end{array}$ & USA & $\begin{array}{l}\text { Neighbourhood } \\
\text { effects }\end{array}$ & $\begin{array}{l}\text { People who } \\
\text { purchased } \\
\text { new/used car }\end{array}$ & 8,981 & $\begin{array}{l}\text { Intentions towards } \\
\text { purchase luxury car } \\
\text { given purchase } \\
\text { behaviour of near } \\
\text { neighbours }\end{array}$ & Yes \\
\hline $\begin{array}{l}\text { Yang and } \\
\text { Allenby } \\
(2003)\end{array}$ & USA & $\begin{array}{l}\text { Neighbourhood } \\
\text { effects }\end{array}$ & Consumers & 857 & $\begin{array}{l}\text { Purchase of mid-size } \\
\text { car }\end{array}$ & No \\
\hline $\begin{array}{l}\text { Zhu and Chao } \\
\text { (2013) }\end{array}$ & USA & $\begin{array}{l}\text { Neighbourhood } \\
\text { effects }\end{array}$ & $\begin{array}{l}\text { Vehicle owners } \\
\text { including AFV }\end{array}$ & 15,884 & $\begin{array}{l}\text { Purchase choice of AFV } \\
\text { as a function of social } \\
\text { characteristics of built } \\
\text { environment }\end{array}$ & Yes \\
\hline $\begin{array}{l}\text { Aini et al. } \\
(2013)\end{array}$ & Malaysia & Social norms & $\begin{array}{l}\text { Government } \\
\text { workers }\end{array}$ & 201 & $\begin{array}{l}\text { Purchase intention } \\
\text { towards AFVs } \\
\text { moderated by } \\
\text { individual personal } \\
\text { norms }\end{array}$ & Yes \\
\hline $\begin{array}{l}\text { Axsen et al. } \\
(2009)\end{array}$ & $\begin{array}{l}\text { USA, } \\
\text { Canada }\end{array}$ & Social norms & $\begin{array}{l}\text { Purchasers of } \\
\text { new vehicle }\end{array}$ & 943 & $\begin{array}{l}\text { Choice between AFV } \\
\text { and conventional }\end{array}$ & No \\
\hline $\begin{array}{l}\text { Dijk et al. } \\
\text { (2013) }\end{array}$ & Netherlands & Social norms & \multicolumn{2}{|c|}{$\begin{array}{l}\text { Simulation of } 100 \text { agents } \\
\text { and } 10 \text { supply companies }\end{array}$} & Market growth & No \\
\hline $\begin{array}{l}\text { Donnelly Jr } \\
\text { and } \\
\text { Ivancevich } \\
\text { (1974) }\end{array}$ & USA & Social norms & Vehicle owners & 641 & $\begin{array}{l}\text { Purchase relative to } \\
\text { launch }\end{array}$ & No \\
\hline $\begin{array}{l}\text { Eggers and } \\
\text { Eggers (2011) }\end{array}$ & Germany & Social norms & Vehicle owners & 242 & Choice between AFVs & No \\
\hline $\begin{array}{l}\text { Gaker et al. } \\
(2010)\end{array}$ & USA & Social norms & Students & 312 & $\begin{array}{l}\text { Choice between AFV } \\
\text { and conventional } \\
\text { vehicle given } \\
\text { knowledge decisions } \\
\text { made by peers }\end{array}$ & Yes \\
\hline $\begin{array}{l}\text { Graham- } \\
\text { Rowe et al. } \\
(2012)\end{array}$ & UK & Social norms & $\begin{array}{l}\text { Trial } \\
\text { participants }\end{array}$ & 40 & $\begin{array}{l}\text { Perceptions of battery } \\
\text { electric vehicle (BEV) }\end{array}$ & No \\
\hline
\end{tabular}




\begin{tabular}{|c|c|c|c|c|c|c|}
\hline $\begin{array}{l}\text { Huétink et al. } \\
\text { (2010) }\end{array}$ & Netherlands & Social norms & \multicolumn{2}{|c|}{$\begin{array}{l}\text { Simulation between } \\
\text { consumers and refuelling } \\
\text { infrastructure }\end{array}$} & Diffusion of AFVs & No \\
\hline $\begin{array}{l}\text { Jansson et al. } \\
(2010)\end{array}$ & Sweden & Social norms & Car owners & 1,832 & $\begin{array}{l}\text { Willingness to adopt a } \\
\text { AFV as a function of } \\
\text { personal norms }\end{array}$ & Yes \\
\hline $\begin{array}{l}\text { Lee et al. } \\
(2013)\end{array}$ & Korea & Social norms & \multicolumn{2}{|c|}{$\begin{array}{l}\text { Simulation grounded in } \\
\text { empirical data from Japan }\end{array}$} & Market Share & No \\
\hline $\begin{array}{l}\text { Mau et al. } \\
(2008)\end{array}$ & USA & Social norms & Vehicle owners & 2,000 & Stated preference & No \\
\hline $\begin{array}{l}\text { Moons and } \\
\text { De } \\
\text { Pelsmacker } \\
(2012)\end{array}$ & Belgium & Social norms & Students & 1,202 & $\begin{array}{l}\text { Intention to adopt AFV } \\
\text { as a function of } \\
\text { subjective norms (peers } \\
\text { and media) }\end{array}$ & Yes \\
\hline $\begin{array}{l}\text { Ozaki and } \\
\text { Sevastyanova } \\
(2011) \\
\end{array}$ & UK & Social norms & Vehicle owners & 1,263 & Purchase motivations & No \\
\hline $\begin{array}{l}\text { Park et al. } \\
\text { (2011) }\end{array}$ & $\begin{array}{l}\text { Korea, } \\
\text { Japan, USA }\end{array}$ & Social norms & \multicolumn{2}{|c|}{$\begin{array}{l}\text { Simulation based on time } \\
\text { series data from Japan }\end{array}$} & Diffusion of AFVs & No \\
\hline $\begin{array}{l}\text { Schuitema et } \\
\text { al. (2013) }\end{array}$ & UK & Social norms & Vehicle owners & 2,729 & $\begin{array}{l}\text { Propensity to adopt } \\
\text { AFV }\end{array}$ & Yes \\
\hline $\begin{array}{l}\text { Wiedmann et } \\
\text { al. (2011) }\end{array}$ & Germany & Social norms & Car owners & 480 & $\begin{array}{l}\text { Social risk involved in } \\
\text { ownership of AFV }\end{array}$ & Yes \\
\hline
\end{tabular}

Of the 43 studies, 4 were qualitative using data collection methods such as ethnography, semistructured interview and social network mapping, and 1 mixed-method study used both quantitative and qualitative approaches. Of the 40 studies that reported quantitative outcomes, 9 were simulations grounded in empirical data of which 5 were agent-based models which explicitly represent social relationships (links) between consumers (nodes) and social network structure. Analytical approaches were dominated by multiple regression methods, with 23 studies modelling the association between social influence and vehicle choice, and 7 studies using a discrete choice framework. Geographically, studies were concentrated in North America with 20 studies drawing samples or empirical data from either the US or Canada. European countries were represented in 16 studies with only 1 study using data from Middle East and 7 from Asia. 
Appendix E - Social Influence Effect Sizes for Individual Countries Estimated from the MetaRegression

\begin{tabular}{|l|l|l|l|l|l|}
\hline Country & $\begin{array}{l}\text { Score on } \\
\text { Pragmatic versus } \\
\text { Normative Scale }\end{array}$ & $\begin{array}{l}\text { Social Influence Effect Size } \\
\text { Adjusted for Cultural } \\
\text { Differences }\end{array}$ & $\begin{array}{l}\text { Standard } \\
\text { Error }\end{array}$ & $\begin{array}{l}\text { Lower } \\
\text { Confidence } \\
\text { Interval }\end{array}$ & $\begin{array}{l}\text { Upper } \\
\text { Confidence } \\
\text { Interval }\end{array}$ \\
\hline Taiwan & 0.93 & 0.023 & 0.083 & -0.272 & 0.188 \\
\hline China & 0.87 & 0.047 & 0.079 & -0.028 & 0.204 \\
\hline Germany & 0.83 & 0.132 & 0.065 & 0.041 & 0.262 \\
\hline Belgium & 0.82 & 0.136 & 0.064 & 0.079 & 0.264 \\
\hline Sweden & 0.53 & 0.256 & 0.043 & 0.218 & 0.342 \\
\hline UK & 0.51 & 0.265 & 0.042 & 0.228 & 0.349 \\
\hline Greece & 0.45 & 0.222 & 0.071 & 0.070 & 0.364 \\
\hline Malaysia & 0.41 & 0.306 & 0.042 & 0.178 & 0.391 \\
\hline Finland & 0.38 & 0.150 & 0.070 & 0.149 & 0.290 \\
\hline USA & 0.26 & 0.368 & 0.050 & 0.287 & 0.469 \\
\hline Iran & 0.14 & 0.418 & 0.061 & 0.345 & 0.540 \\
\hline
\end{tabular}


Appendix F - Summary of the use of control variables between studies

\begin{tabular}{|c|c|c|c|}
\hline $\begin{array}{l}\text { Type of social influence and related } \\
\text { studies included in meta-analysis }\end{array}$ & $\begin{array}{l}\text { Studies control for } \\
\text { variation in individual } \\
\text { characteristics }\end{array}$ & $\begin{array}{l}\text { Studies control } \\
\text { for variation in } \\
\text { physical } \\
\text { environment }\end{array}$ & $\begin{array}{l}\text { Studies control for } \\
\text { variation in vehicle } \\
\text { characteristics }\end{array}$ \\
\hline \multicolumn{4}{|l|}{ Interpersonal communication } \\
\hline $\begin{array}{l}\text { Axsen et al. (2013), Baltas and Saridakis } \\
\text { (2013), Hsu et al. (2013), Hutter et al. } \\
\text { (2013), Kulkarni et al. (2012), } \\
\text { Mohammad Reza and Neda (2012), Sha } \\
\text { et al. (2012), Zhang et al. (2011) }\end{array}$ & Yes & No & Some evidence \\
\hline \multicolumn{4}{|l|}{ Neighbourhood effect } \\
\hline $\begin{array}{l}\text { Adjemian et al. (2010), Goetzke and } \\
\text { Weinberger (2012), Grinblatt et al. } \\
\text { (2008), Heutel and Muehlegger (2010), } \\
\text { McShane et al. (2012), Shemesh and } \\
\text { Zapatero (2014), Zhu and Chao (2013) }\end{array}$ & Yes & Yes & Yes \\
\hline \multicolumn{4}{|l|}{ Social Norms } \\
\hline $\begin{array}{l}\text { Aini et al. (2013), Gaker et al. (2010), } \\
\text { Jansson et al. (2010), Moons and De } \\
\text { Pelsmacker (2012), Schuitema et al. } \\
\text { (2013), Wiedmann et al. (2011) }\end{array}$ & Yes & No & Yes \\
\hline
\end{tabular}

The table illustrates the use of control variables within studies distinguishing between (a) individual characteristics such as income, education and gender (b) the physical environment such as rural or urban setting, type of residential environment and (c) vehicle characteristics such as type of fuel, speed, range, price etc. It shows there is some commonality in model specification (and use of control variables) between studies that frame specific types of social influence. For example studies which measure 'neighbourhood effects' measure auto-spatial correlation controlling for other sources of homogeneity between individuals such as income and education. In our analysis we find no significant differences in the size of the social influence effect between social influence types suggesting that these control variables do not unequally bias the outcome effects of each study above the design effect already discussed in Section 4.2. We conclude that the final estimate of social influence effect size of 0.241 is likely to be conservative and probably more likely to lie in its upper $95 \%$ confidence range $(0.241-0.322)$ because it relies on the partial effects of social influence measured in studies. This conclusion is based on the two post-hoc sensitivity analyses already completed. There is a significant design effect which we suggest is evidence of downwards suppression of effect size particularly within discrete choice experiments which control for the strong income/price effects on vehicle choice. There is however, no significant differences in effect size between studies which measure particular types of social influence suggesting emphasis on specific control mechanism does not unequally bias effect sizes between studies. 
